\title{
Quantitative Minerological Analysis of Some Granite Rocks of Deoghar Jharkhand
}

\author{
P.K.Srivastava ${ }^{1}$, A.P.Krishna ${ }^{2}$, Shadab Jawed ${ }^{1} \&$ Pallavi Sarkhel $^{1}$ \\ ${ }^{1}$ Department of Chemistry, Birla Institute of Technology, Mesra, Ranchi-835215, Jharkhand, India \\ ${ }^{2}$ Department of Remote Sensing, Birla Institute of Technology, Mesra, Ranchi-835215, Jharkhand, India \\ Correspondence: P.K.Srivastava, Department of Chemistry, Birla Institute of Technology, Mesra, Ranchi-835215, \\ Jharkhand, India
}

Received: March 8, 2020

doi:10.5539/esr.v9n2p30

\author{
Accepted: April 7, 2020 \\ Online Published: May 10, 2020 \\ URL: https://doi.org/10.5539/esr.v9n2p30
}

\begin{abstract}
Crystalline minerals in granite rocks has been quantatively analysed by powder X-ray diffraction (XRD) and Scanning Electron Microscope supported with Energy Dispersed Spectroscopy (SEM-EDS). SEM microphotograph reveals that rock is dominated by brightly illuminated quartz imbedded in the matrix with mica and other minor minerals. The X-ray mineral composition data have been plotted with SEM-EDS mineral composition, data shows that the composition obtained by two technique are in consistent within the experimental limit and in good agreement. Further plot of chemical composition of constituent oxides of granite sample by XRD and SEM-EDS confirm the consistency of two technique and similarity with Jharkhand mean granite composition. Silica composition have been plotted with trace element $\mathrm{Pb}, \mathrm{Ba}, \mathrm{Zr}$, $\mathrm{Rb}$, and Alumina composition with $\mathrm{Pb}, \mathrm{Ba}, \mathrm{Zr}$ and $\mathrm{Rb}$ shows that these elements are randomly imbedded in the matrix with almost uniform composition. $\mathrm{Al}_{2} \mathrm{O}_{3}$ composition have been plotted with $\mathrm{Ba}, \mathrm{Pb}$, and $\mathrm{Zr}$ shows almost constant composition in all the five samples. Based on XRD and SEM-EDS results, it was reveals that granite sample from the study areas are peraluminius rocks composed of mainly quartz, muscovite, kaolinite, chlorite and albite.
\end{abstract}

Keywords: granite rocks, peraluminius rocks, SEM-EDS, Mineral composition, X-ray diffraction (XRD), SEM microphotographs

\section{Introduction}

Abraham Werner gave the first definition of granite "Granite is an aggreagate rock which consist of Quatz, Fieldspar and Mica united each other in granular texture (Middlemost 1986). Jharkhand is one of the leading mineral producing states. It is one of the leading producers of coal, kyanite, gold, silver, bauxite, feldspar, uranium, quartz and colour granite. Jharkhand have high grade metamorphic rocks which have undergone metamorphism under amphibolite to granulite facies (Fisher 1984). Granite rocks(Indian Mineral Year Book 2015) are produced from many quarries located throughout the Jharkhand for mixing and matching stone.Granites are coarse-grained rocks with a mottled appearance. They comprise a mixture of glassy white, pink or red alkali feldspar, minor amounts of dark minerals, and often white, sodic plagioclase (Amral 2006). Their low density and resistance to weathering means that they usually form high, rugged terrains. Faryada and co-worker $(1995,2015,2020)$ have studied minerals and their textures in high pressure or ultra-high pressure (U) HP) metamorphic rocks provide quantitative evidence about the thermal regime during subduction, the depths that the rocks reached and their rates of exhumation. However, these rocks commonly display a pervasive amphibolite to high-temperature (HT) granulite facies overprint of the (U)HP mineral assemblages that was evidently imposed during exhumation, yet the mechanism causing the warmer thermal regime remains unclear.

Geologists use it either in a restricted sense, or as a blanket term for granitoids of acid or intermediate composition (Klika 2016). Their complex of varied origins give rise to a great variety of types. Granites are normally classified on the basis of their relative model proportions of quartz, alkali feldspar and plagioclase. Chemical classification (Seven 2009) based on the principle of alumina saturation has been discussed. These are peralkaline, meta-luminous, sub-aluminous and peraluminous. Granitoid rocks in bulk chemical compositions also contain distinctive suites of minor minerals. Granites have a broad range of physical and chemical properties. The suitability of a granite for any purpose is decided by its physical properties which meet the specification established for the purpose. Granites are mostly used because of their pleasing appearance and physical strength. Chemical properties are less important than the physical properties. However, the chemical composition determines many physical properties of granites, particularly its resistance to weathering. D B Clarke, (Clarke 1992) was of the opinion that the chemical composition of a granitoid rock or any igneous rock, reflects sum of the effects of the source and subsequent processes. The composition of the source rock (Chirsty 2016) has the most 
important influence on the composition of the rock and contain chemical fingerprint of the source material. We determine the mineralogical composition of granite by two different methods. Quantitative characterisation of mineral phases of granite stones are not available in spite of advance analysis instruments and software. Therefore this study with advance analytical instruments will be helpful in deciding the better and efficient applications granite rocks.

\section{Experimental}

Five samples (approx. 1-3 kg each) from Deoghar district were collected and analysed for major oxides and trace elements. The average chemical index of alteration (CIA) value of all samples is 48 (Shao and Yang 2012, Behzad et.al 2016), which lies within the accepted 30-55 range for unweathered granites. Loss on ignition (LOI) was determined by calcining the samples for 2 hours at $900^{\circ} \mathrm{C}$ in an electric furnace. Whole rock powders were analysed for major and minor elements using X-Ray diffractometer(Rigaku Japan) and Scanning Electron Microscope supported by Energy Dispersive Spectrophotometer (SEM -EDS) (Jeol, Japan; JSM-6390LV) .The Chemical compositions are analyzed by EDS. The accuracy of the analyses (Carton and Lyman 2004) for the major elements is better than $1 \%$ for $\mathrm{SiO}_{2}$ and $2 \%$ for other major elements, $2-5 \%$ for minor elements and better than $10 \%$ for trace elements. The precision of the data was expressed as the residual standard deviation (RSD), which in general for all the trace elements is much less than $4 \%$.

\section{X-Ray Diffraction (XRD)}

In order to determine the mineral content in rock power samples were characterised by X-ray diffractometer (XRD).The corresponding spectrum of samples S1A to S5A are shown in figure 1-5 and analysed results (Zhoua et.al. 2018, Hubbard et.al. 1988,Omotoso et.al 2006) are recorded in table 1.

Table 1. Composition of granite rock minerals of sample S1A to S5A

\begin{tabular}{|c|c|c|c|c|c|c|}
\hline $\begin{array}{l}\text { Constituentsmi } \\
\text { nerals }\end{array}$ & $\begin{array}{lll}\begin{array}{l}\text { Granite } \\
\text { standard }\end{array} & \% & \mathrm{JH} \\
\end{array}$ & S1A & S2A & S3A & S4A & S5A \\
\hline $\mathrm{SiO} 2$ & 75.01 & 75.50 & 74.05 & 73.60 & 75.20 & 74,45 \\
\hline $\mathrm{Al} 2 \mathrm{O} 3$ & 12.27 & 12.30 & 12.80 & 13.10 & 13.50 & 12.90 \\
\hline $\mathrm{Fe} 2 \mathrm{O} 3$ & 0.8 & 0.82 & 0.89 & 0.76 & 0.72 & 0.82 \\
\hline $\mathrm{FeO}$ & 2.72 & 1.95 & 2.20 & 2.50 & 2.60 & 1.90 \\
\hline $\mathrm{MgO}$ & 0.08 & 0.20 & 0.25 & 0.15 & 0.35 & 0.10 \\
\hline $\mathrm{CaO}$ & 1.87 & 1.82 & 1.75 & 1.65 & 1.30 & 1.50 \\
\hline $\mathrm{Na} 2 \mathrm{O}$ & 3.36 & 3.35 & 3.25 & 3.50 & 3.28 & 3.50 \\
\hline $\mathrm{K} 2 \mathrm{O}$ & 2.80 & 2.75 & 2.95 & 2.80 & 2.65 & 2.85 \\
\hline $\mathrm{TiO} 2$ & 0.33 & 0.25 & 0.30 & 2.50 & 2.75 & 2.80 \\
\hline $\mathrm{MnO}$ & 0.06 & 0.05 & 0.05 & 0.05 & 0.06 & 0.05 \\
\hline Total \% & 99.30 & 99.19 & 98.49 & 100.61 & 102.41 & 100.87 \\
\hline
\end{tabular}

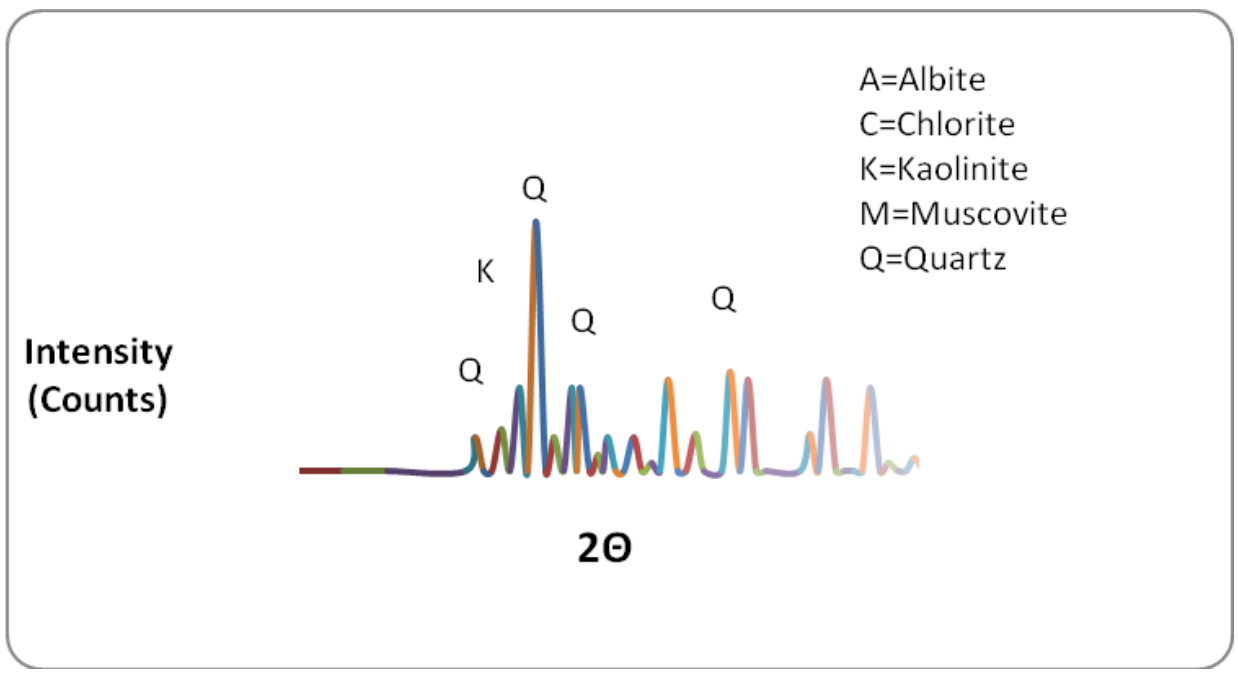

Figure 1. X-Ray Diffractogram of sample S1A 


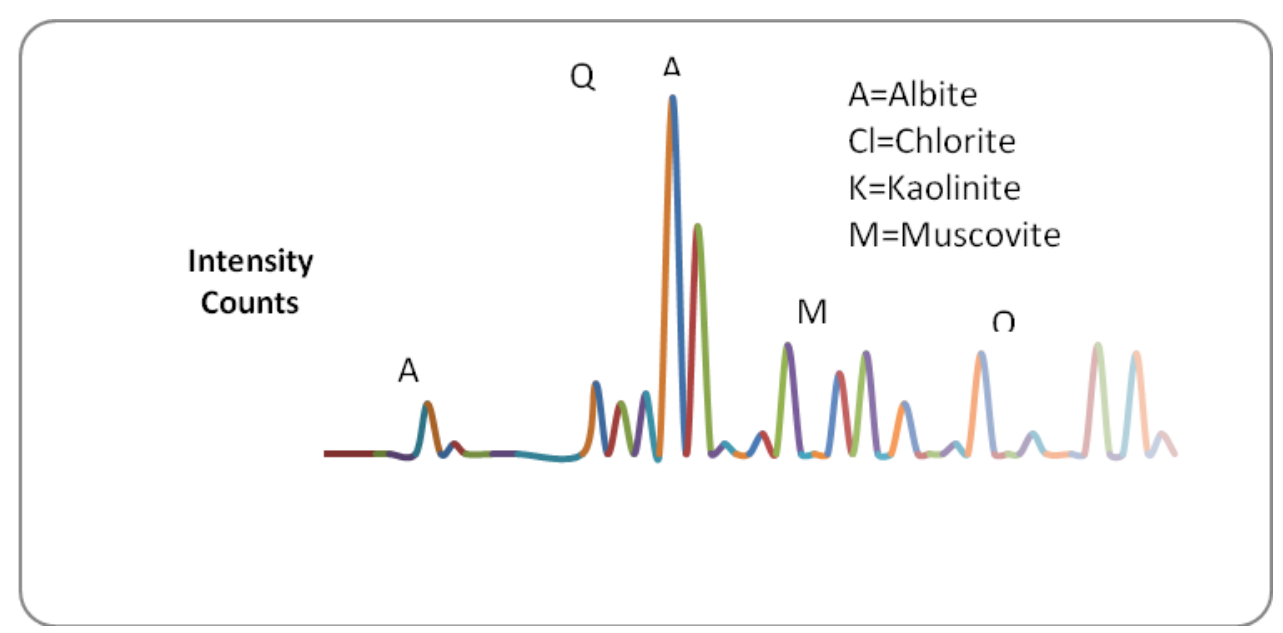

Figure 2. X-ray Diffractogram of Sample S2A

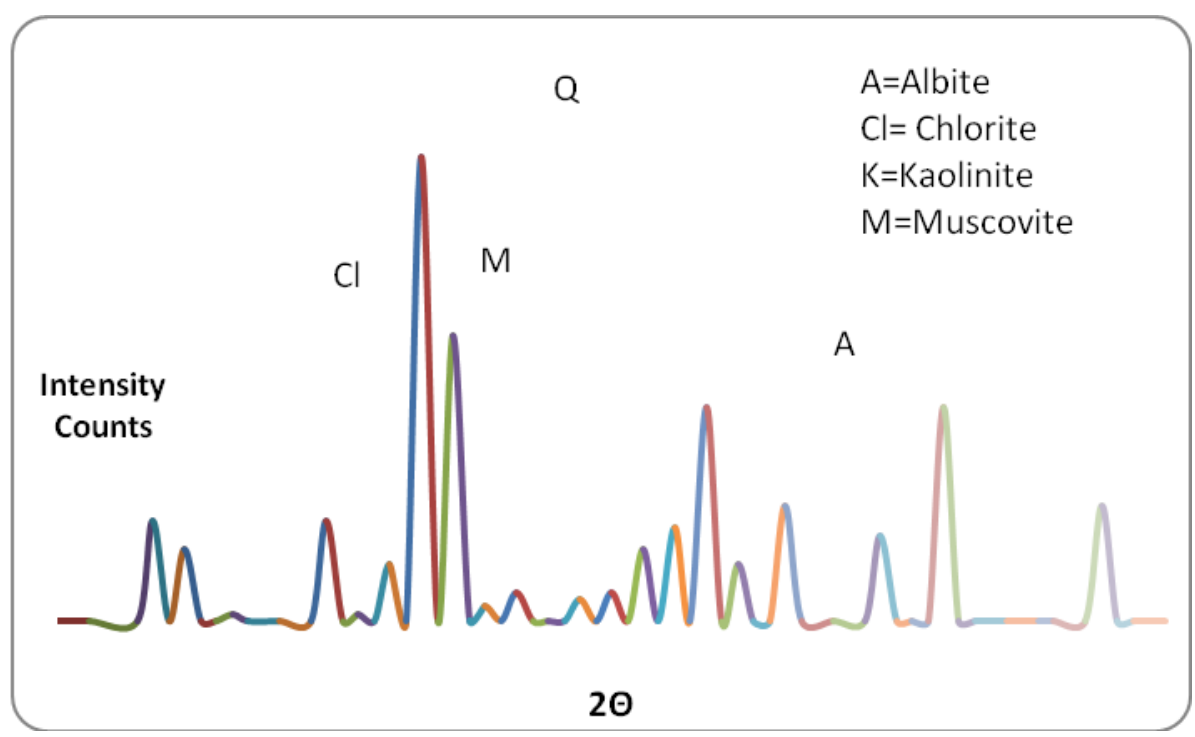

Figure 3. X-Ray Diffractogram of Sample S3A

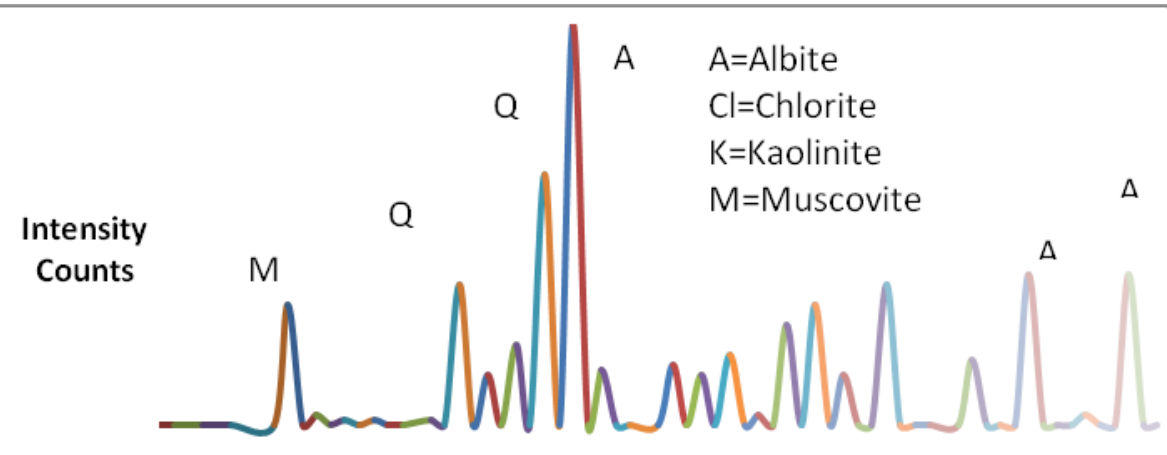

20

Figure 4. X-Ray Diffractogram of Sample S4A 


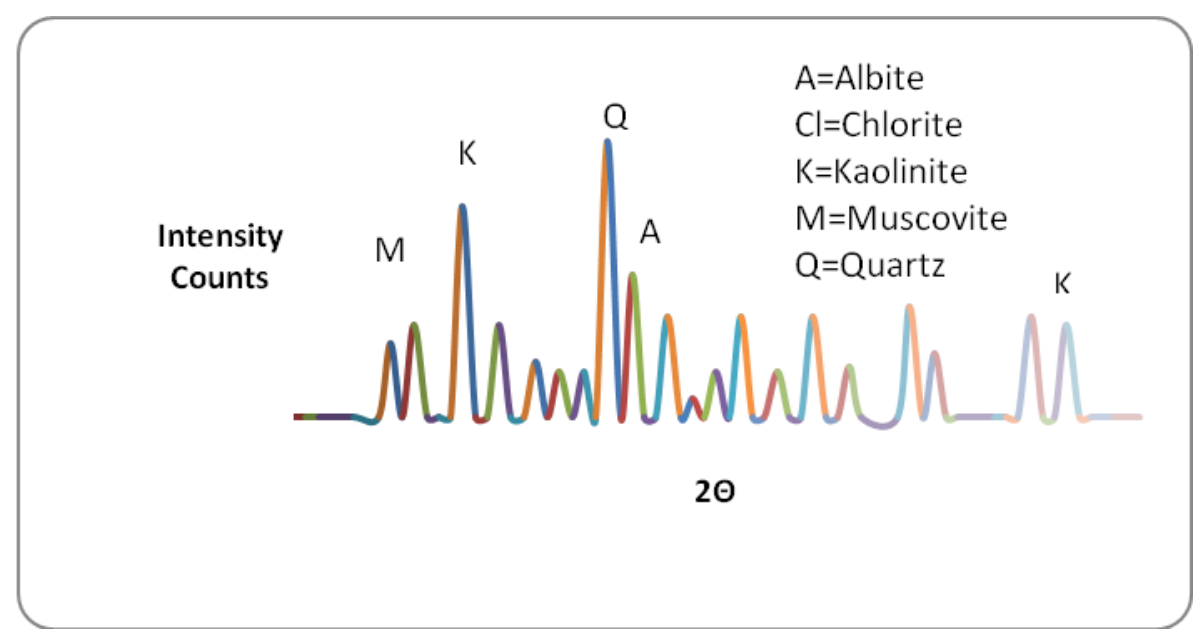

Figure 5. X-Ray Diffractogram of Sample S5A

The plot of intensity counts against $2 \Theta$ shows different peaks in $2 \Theta$ the presence of quartz, muscovite, chlorite, albite, kaolinite, pyrite, K-fieldspar, biotite, amphibole, illite, calcite, plagioclase and apatite in different proportion in some of the samples. Some of the $2 \Theta$ peaks are very weak and hidden. At least six type of constituents minerals were identified in major to miner quantity.. Quartz was dominant 73.60 to $75.50 \%$ and muscovite was in between $12.30-13.50 \%$. In addition to these eight types of minerals iron titanium oxides zircon and rare earth elements also present in small amount as shown in table 3. X-Ray diffraction studies indicate that most abundant phase in granite sample is quartz $\mathrm{SiO}_{2}, \mathrm{~K}$ feldspar-orthoclase ( $\left.\mathrm{KAlSi}_{3} \mathrm{O}_{8}\right)$, Na-feldspar, albite, mica group muscovite $\left(\mathrm{KAl}_{2}\left(\mathrm{Al} \mathrm{Si}_{3} \mathrm{O}_{10}\right)(\mathrm{F}, \mathrm{OH})_{2}\right)$, biotite, $\mathrm{K}(\mathrm{Mg}$, $\mathrm{Fe})_{3}\left(\mathrm{Al} \mathrm{Si}_{3} \mathrm{O}_{10}\right)(\mathrm{F}, \mathrm{OH})_{2}$, Kaolinite $\left(\mathrm{Al}_{2} \mathrm{Si}_{2} \mathrm{O}_{5}(\mathrm{OH})_{4}\right.$ and hematite $\left(\mathrm{Fe}_{2} \mathrm{O}_{3}\right)$ and trace amount of halite gypsum $(\mathrm{NaCl})$ and $\left(\mathrm{CaSO}_{4} 2 \mathrm{H}_{2} \mathrm{O}\right)$.

\section{Scanning Electron Microscope (SEM) Coupled With Energy Dispersive Spectroscopy (EDS) Analysis}

The morphology of surface of granite samples S1A - S5A are shown in figure 6-10.The SEM- EDS spectra are shown in figure 11-15 and corresponding oxides are shown in table 2. The slight deviation in value than $100 \%$ may be attributed to elemental interference, matrix effect and overlap effect. At least, ten types of constituent minerals were identified in the granite sample. Quartz was a dominant constituent with more than $70 \%$ and second is muscovite, K-feldspar and alkali feldspar were contained in higher concentration than plagioclase. In addition to these minerals, iron-titanium oxide, zircon and rare earth elements were also observed in a small amount. The present composition was characteristic of the ordinary granite. Iron-titanium oxide, pyroxene, apatite and pyrite were also observed in a small amount.

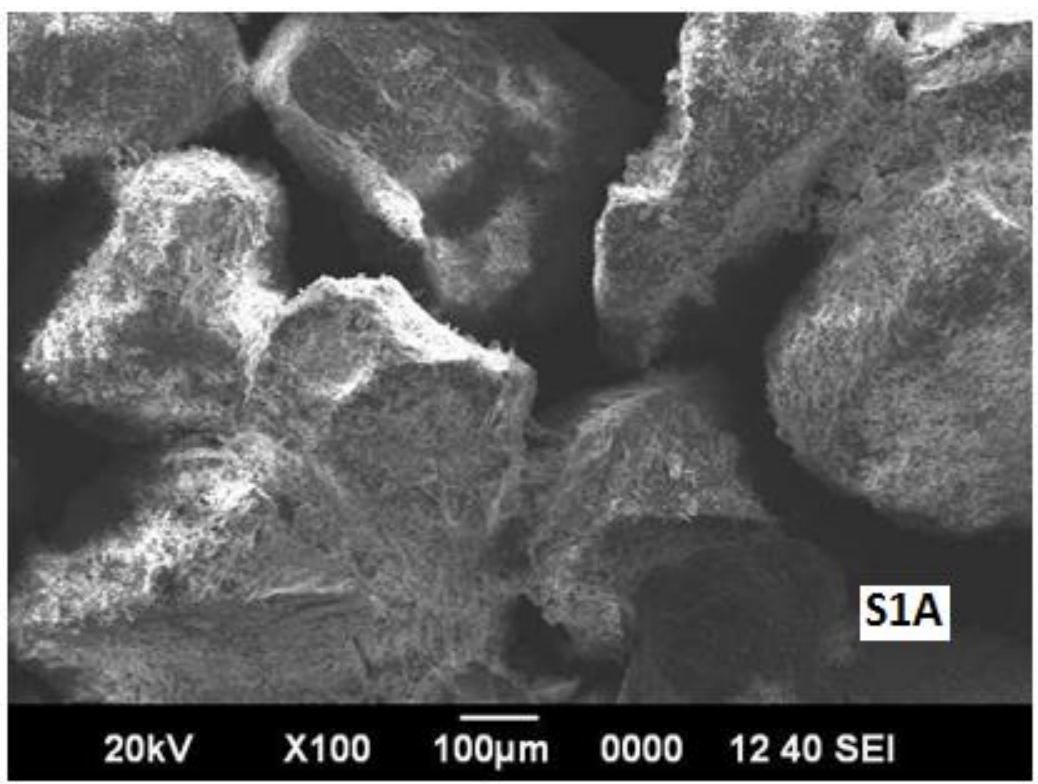

Figure 6. SEM photograph of samples S1A 


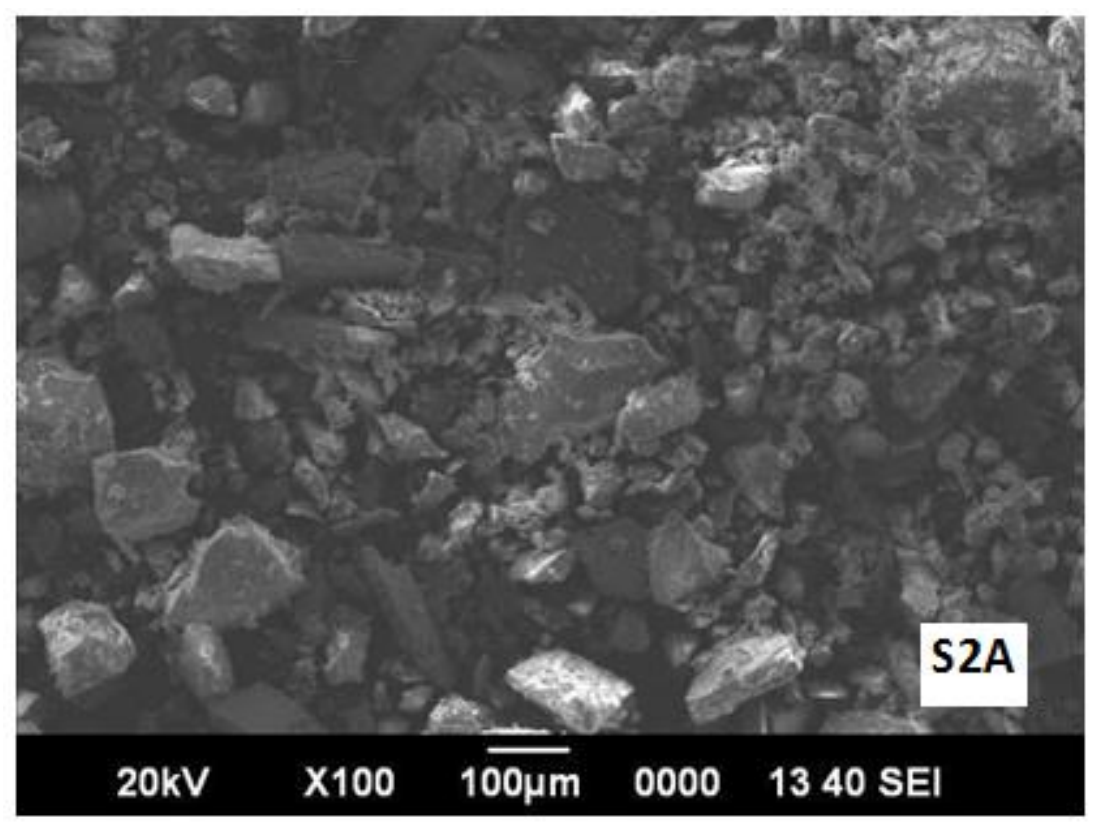

Figure 7. SEM photograph of sample S2A

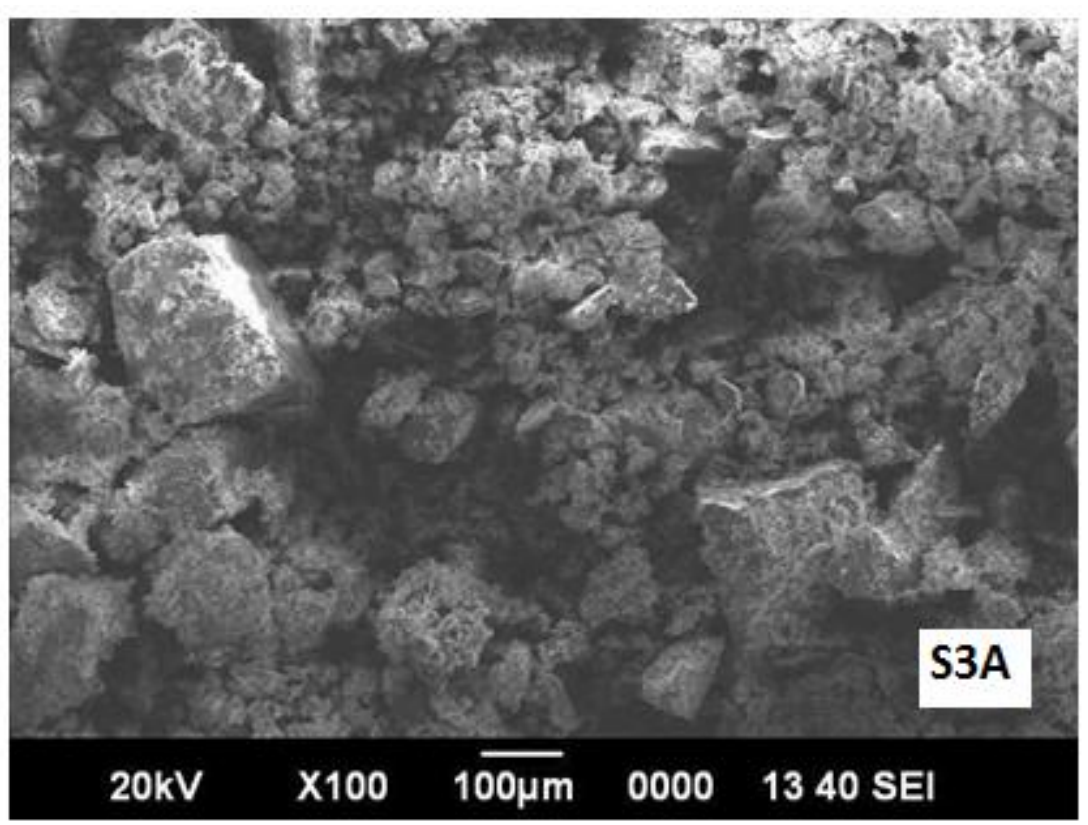

Figure 8. SEM photograph of sample S3A 


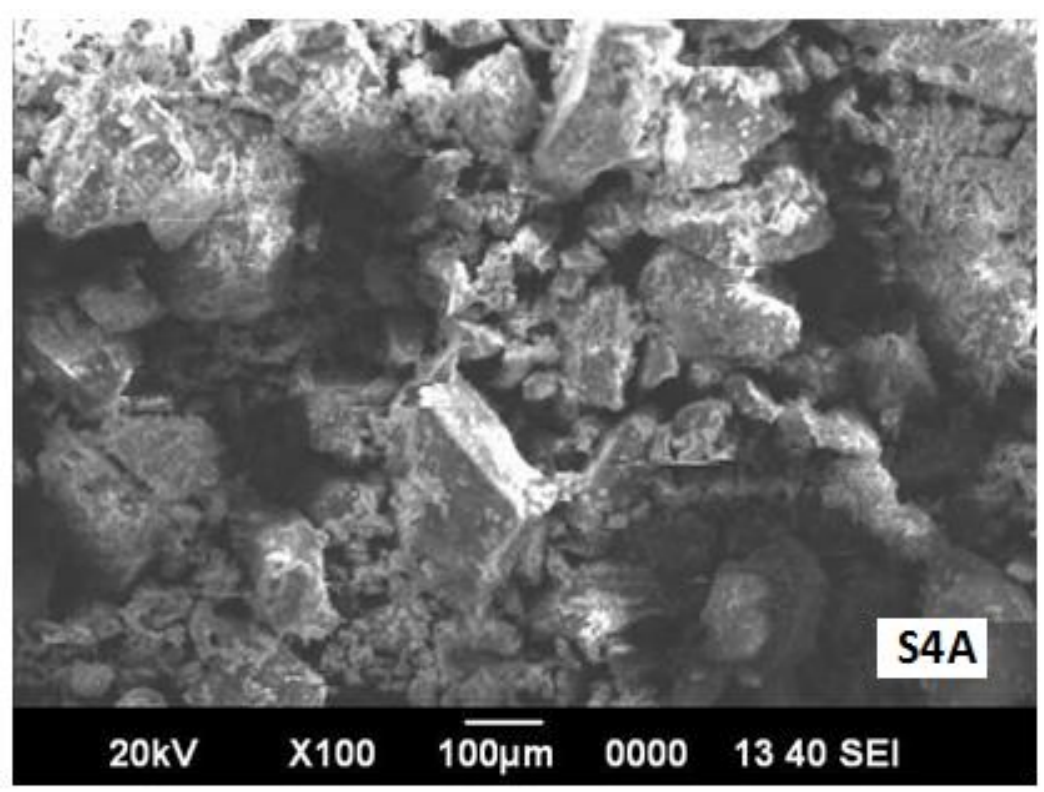

Figure 9. SEM photograph of sample S4A

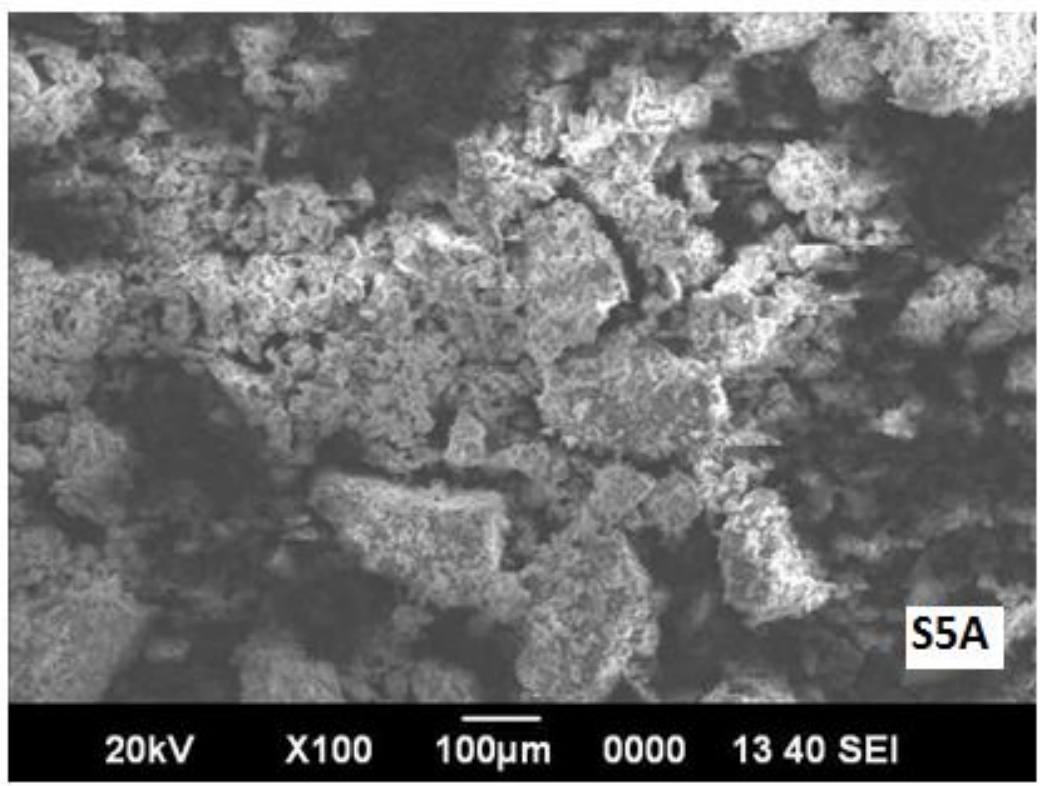

Figure 10. SEM photograph of sample S5A

Table 2. Quantitative chemical analysis of granite by SEM-EDS constituent oxides of sample S1A - S5A and granite \% of Jharkhand

\begin{tabular}{|l|l|l|l|l|l|l|}
\hline Constituent Oxides & $\begin{array}{l}\text { Granite \% standard } \\
\mathrm{JH}\end{array}$ & $\mathrm{S} 1 \mathrm{~A}$ & $\mathrm{~S} 2 \mathrm{~A}$ & $\mathrm{~S} 3 \mathrm{~A}$ & S4A & S5A \\
\hline $\mathrm{SiO}_{2}$ & 75.01 & 70.30 & 72.45 & 70.40 & 72.25 & 71.50 \\
\hline $\mathrm{Al}_{2} \mathrm{O}_{3}$ & 14.21 & 15.35 & 13.60 & 15.15 & 14.35 & 13.95 \\
\hline $\mathrm{Fe}_{2} \mathrm{O}_{3}$ & 0.8 & 0.72 & 0.79 & 0.86 & 0.82 & 0.95 \\
\hline $\mathrm{FeO}$ & 2.72 & 1.55 & 2.25 & 2.30 & 2.50 & 1.75 \\
\hline $\mathrm{MgO}$ & 0.08 & 0.30 & 0.15 & 0.18 & 0.18 & 0.25 \\
\hline $\mathrm{CaO}$ & 1.87 & 1.12 & 1.25 & 1.35 & 1.25 & 1.45 \\
\hline $\mathrm{Na} O$ & 3.36 & 3.30 & 3.55 & 2.70 & 2.85 & 2.90 \\
\hline $\mathrm{K}_{2} \mathrm{O}$ & 2.80 & 3.55 & 3.65 & 2.95 & 3.60 & 3.15 \\
\hline $\mathrm{TiO}_{2}$ & 0.33 & 0.24 & 0.29 & 2.35 & 2.55 & 2.55 \\
\hline $\mathrm{MnO}$ & 0.06 & 0.03 & 0.06 & 0.06 & 0.08 & 0.04 \\
\hline $\mathrm{Total} \%$ & 101.24 & 96.26 & 98.04 & 98.30 & 100.43 & 98.49 \\
\hline
\end{tabular}




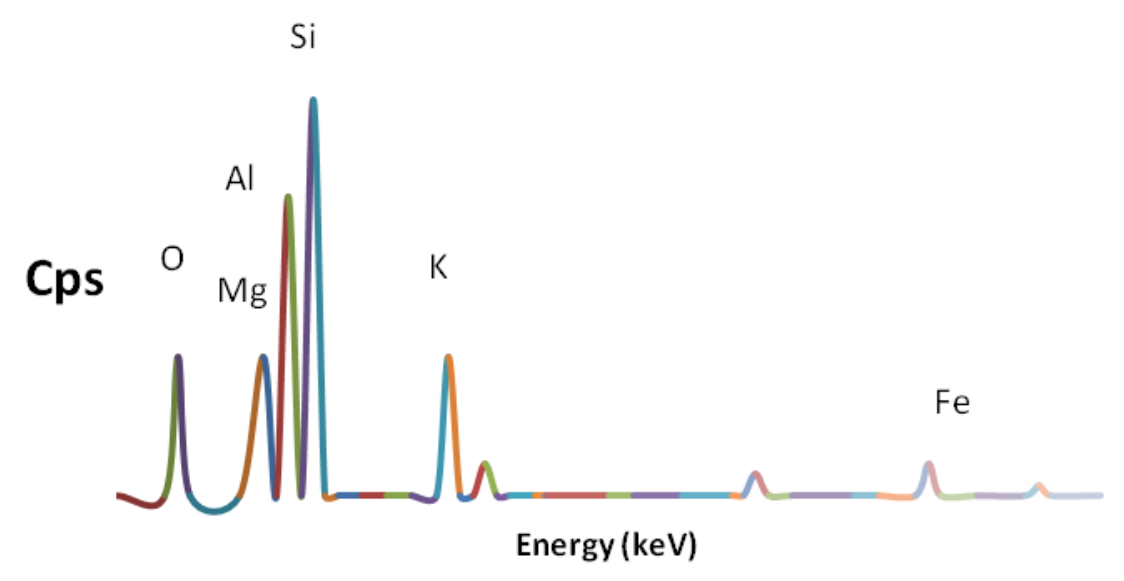

Figure 11. EDS Spectrum of Sample S1A

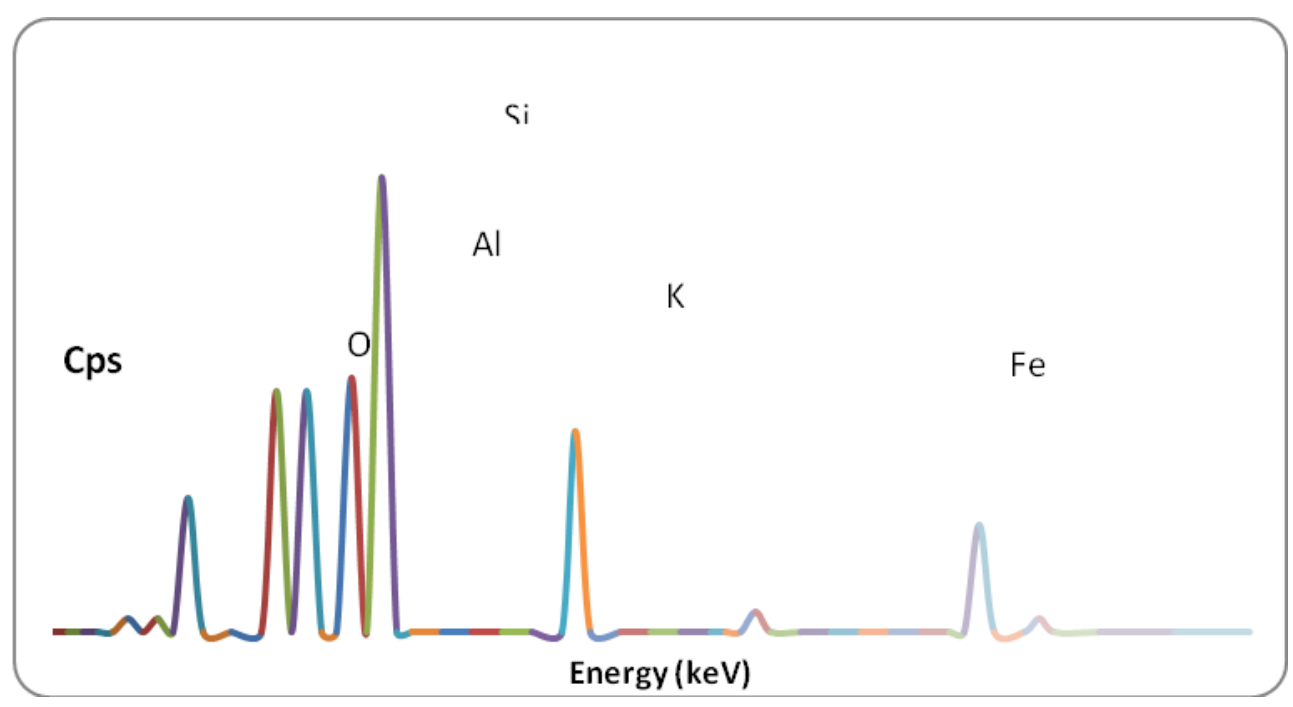

Figure 12. EDS Spectrum of Sample S2A

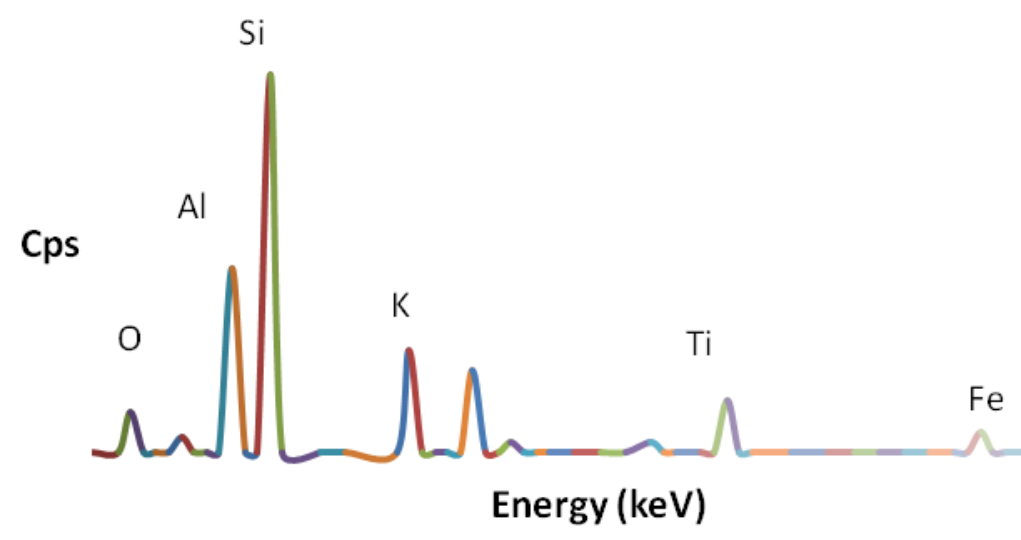

Figure 13. EDS Spectrum of SampleS3A 


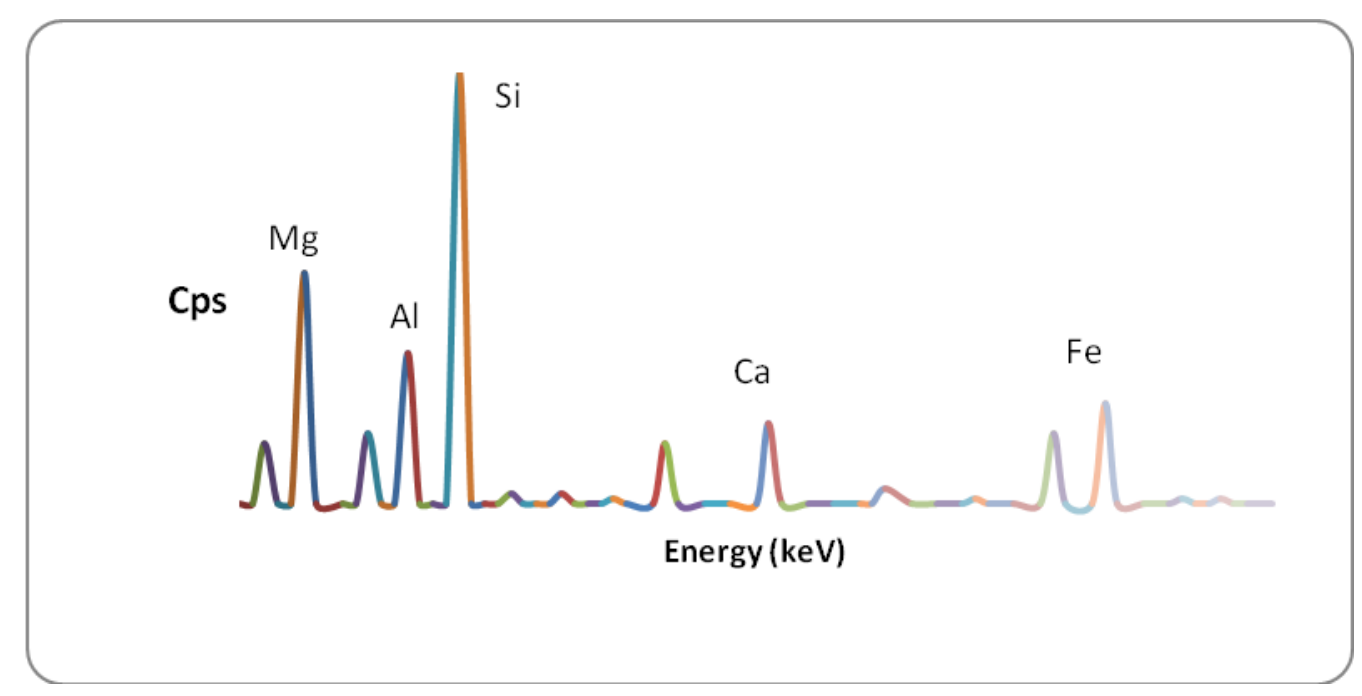

Figure 14. EDS Spectrum of Sample S4A

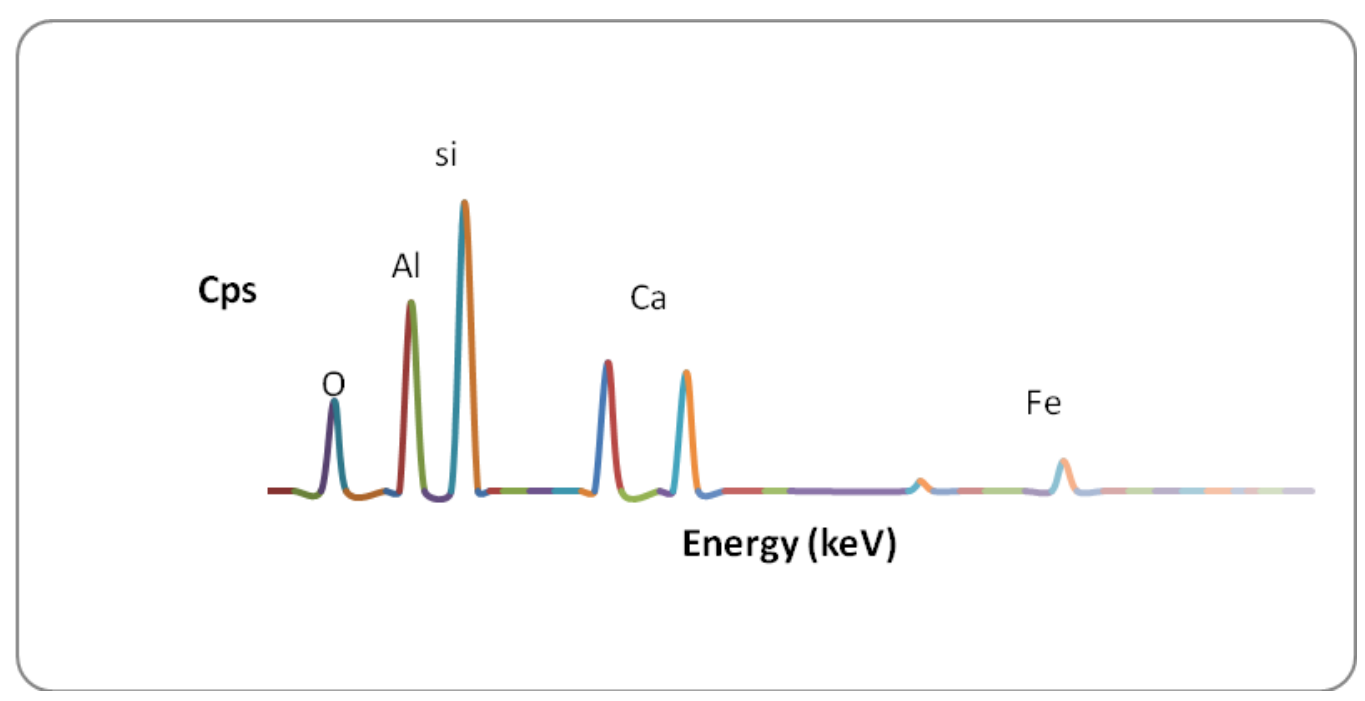

Figure 15. EDS Spectrum of Sample S5A

Figure 11 to 15 shows the results of Energy Dispersive X-Ray Spectroscopy (EDS) characterization of granite sample S1A -S5A. The spectrum of EDS analysis indicates the presence Oxygen $(\mathrm{O})$, Magnesium $(\mathrm{Mg})$, Aluminium $(\mathrm{Al})$, Silicon $(\mathrm{Si})$, Potassium $(\mathrm{K})$, Calcium $(\mathrm{Ca})$ and Titaniumin in the granite sample table 2 . The sum of the percentages of constituents minerals in samples are not exactly $100 \%$, this is attributed to elemental interference, matrix effect and overlap effect. The highest element contents were shown by samples are silicon. It confirmed that silicate is the major mineral phase followed by alumina.

\section{Comparison of Data Measured by XRD and SEM-EDS Two Technique}

Oxides compositions in granite by two technique XRD and SEM-EDS for $\mathrm{Na}, \mathrm{Mg}, \mathrm{Al}, \mathrm{Si}, \mathrm{Ca}, \mathrm{Ti}, \mathrm{Fe}$ etc. have been plotted in figure $16-22$. The comparison of \% XRD data with \% composition determined by SEM-EDS of Al2O3, $\mathrm{SiO} 2, \mathrm{Na} 2 \mathrm{O}$, $\mathrm{K} 2 \mathrm{O}, \mathrm{FeO}, \mathrm{TiO} 2$, and $\mathrm{MnO}$ shows that data are comparable within experimental error and also comparable with mean composition value of Jharkhand granite. All the five samples S1A to S5A shows that both the technique results are comparable within experimental error. 


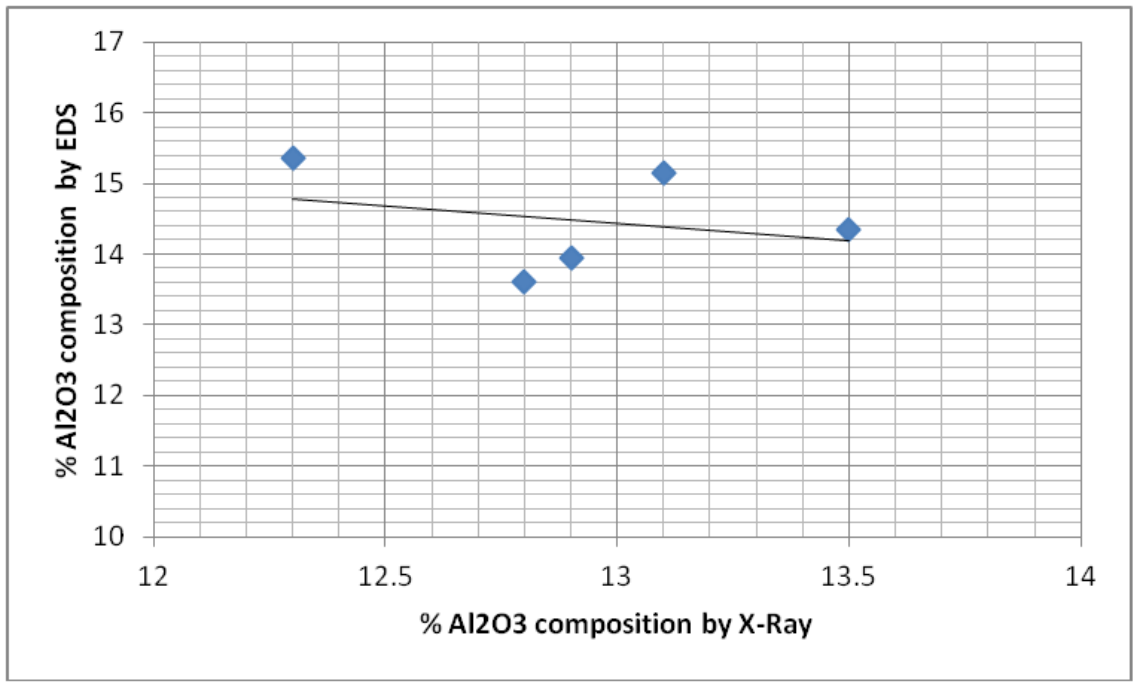

Figure 16. Plot of $\% \mathrm{Al}_{2} \mathrm{O}_{3}$ composition by X-ray against $\% \mathrm{Al}_{2} \mathrm{O}_{3}$ composition determined by SEM-EDS

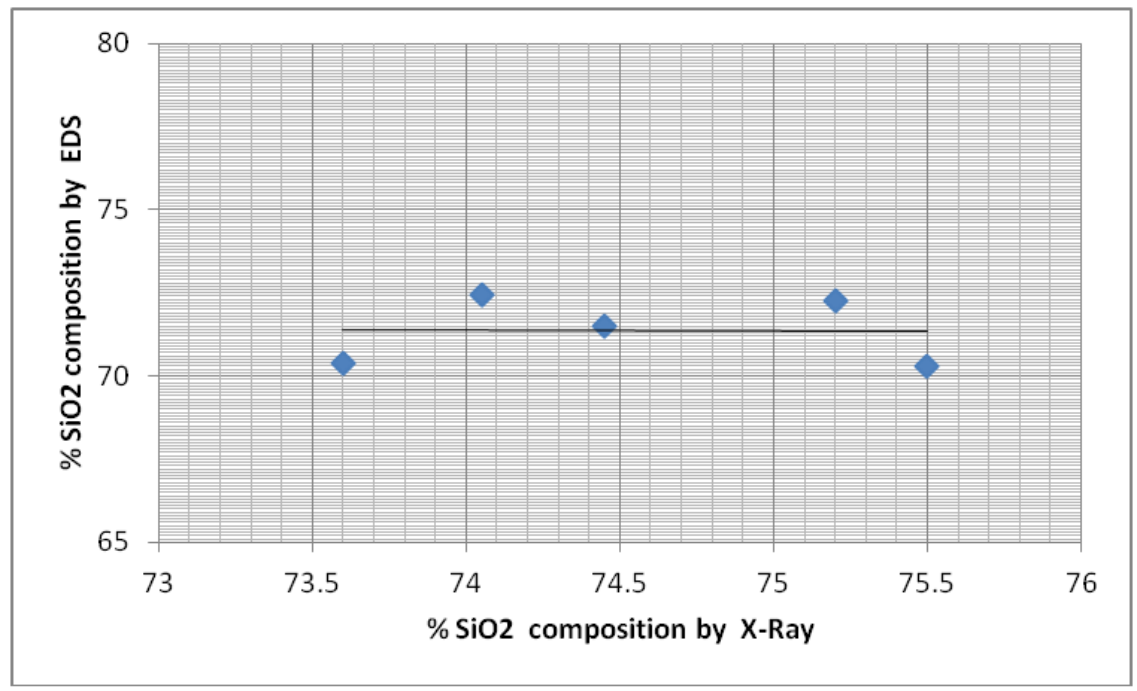

Figure 17. Plot of $\% \mathrm{Si}_{2} \mathrm{O}_{3}$ composition by $\mathrm{X}$-ray against $\% \mathrm{Si}_{2} \mathrm{O}_{3}$ composition determined by SEM-EDS

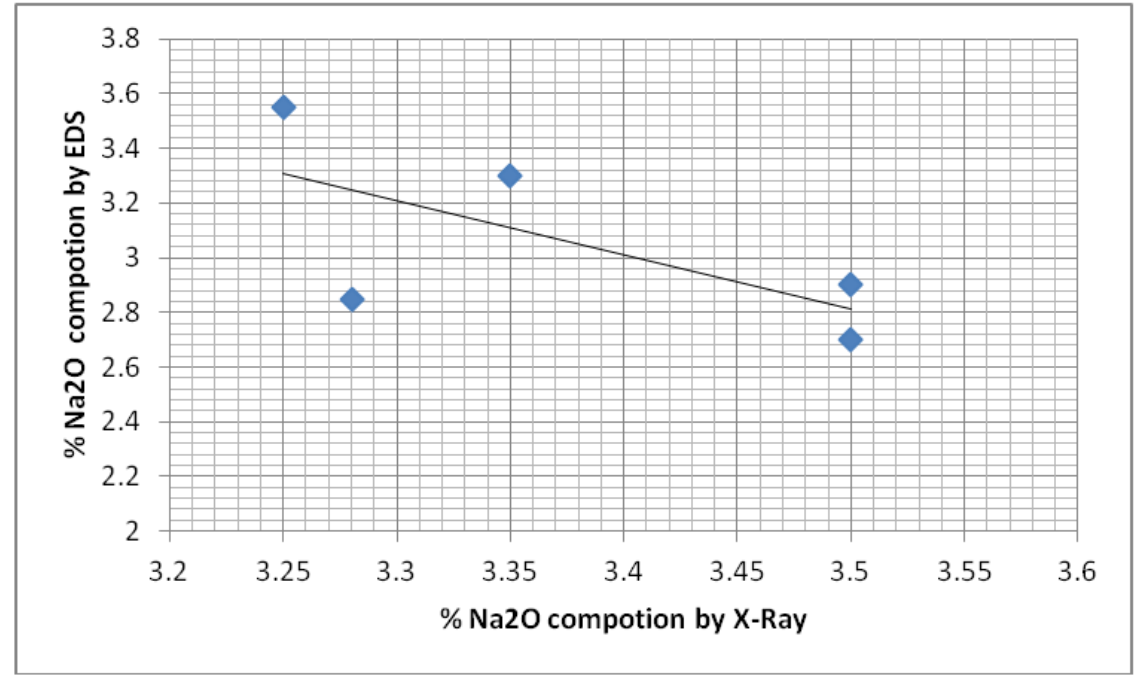

Figure 18. Plot of $\% \mathrm{Na}_{2} \mathrm{O}$ composition by X-ray against $\% \mathrm{Na}_{2} \mathrm{O}$ composition determined by SEM-EDS 


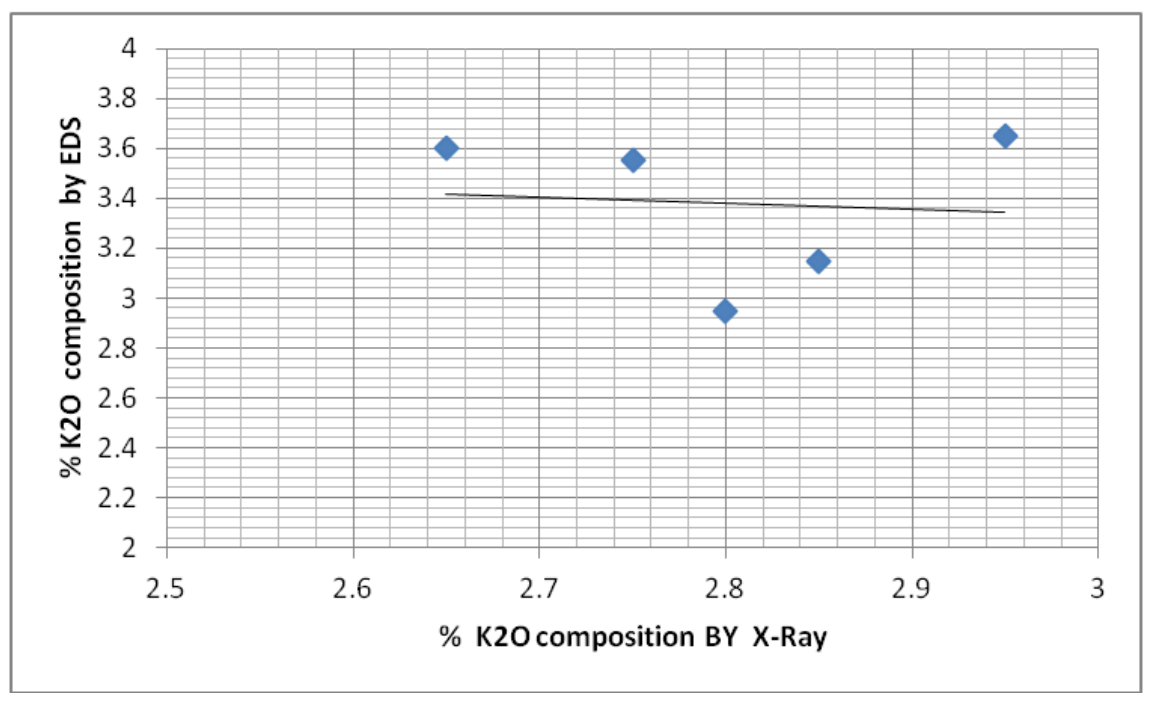

Figure 19. Plot of $\% \mathrm{~K}_{2} \mathrm{O}$ composition by $\mathrm{X}$-ray against $\% \mathrm{~K}_{2} \mathrm{O}$ composition determined by SEM-EDS

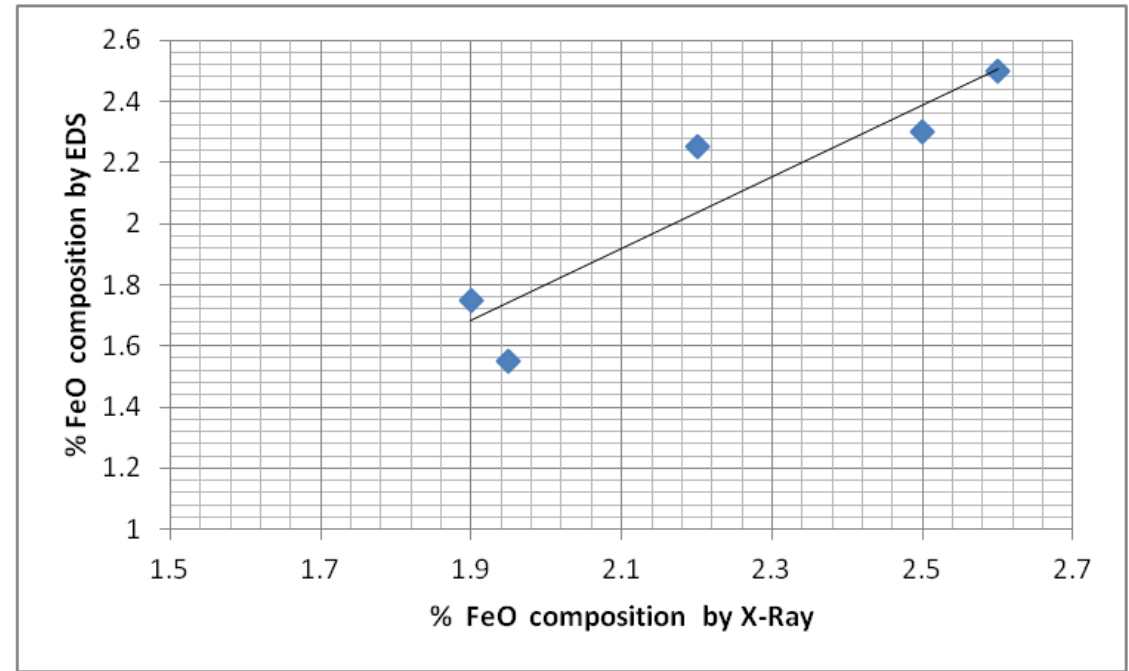

Figure 20. Plot of $\% \mathrm{FeO}$ composition by $\mathrm{X}$-ray against $\% \mathrm{FeO}$ composition determined by SEM-EDS

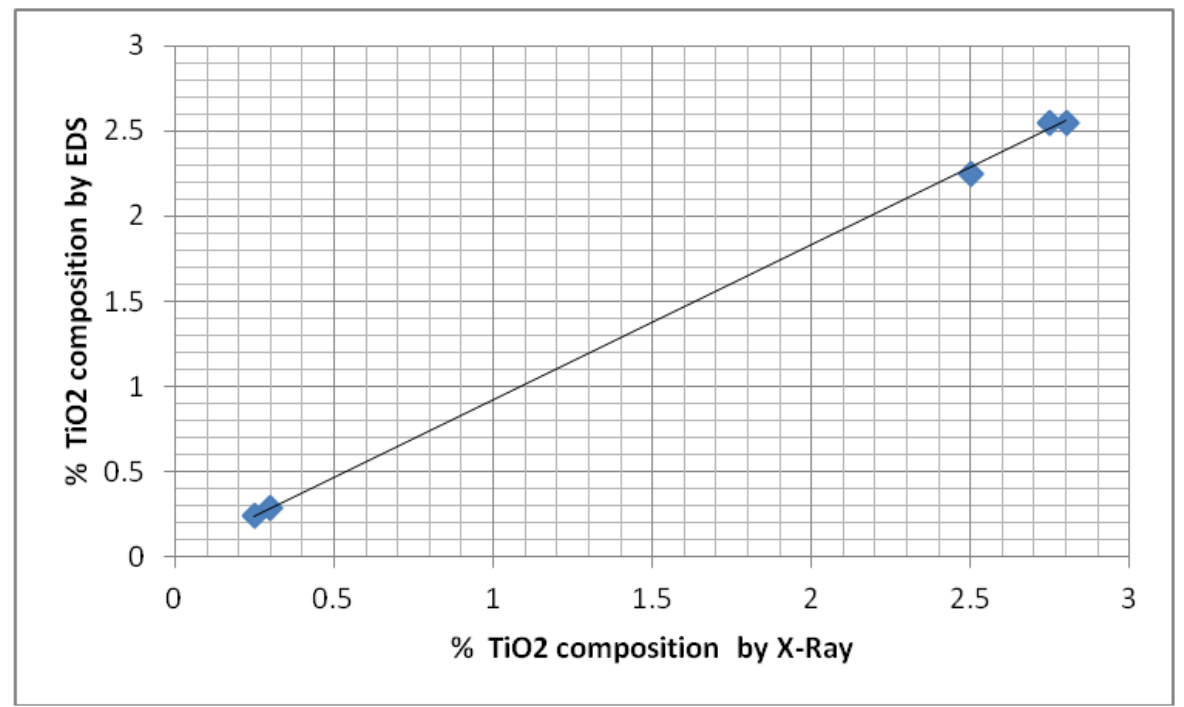

Figure 21. Plot of $\% \mathrm{TiO}_{2}$ composition by $\mathrm{X}$-ray against $\% \mathrm{TiO}_{2}$ composition determined by SEM-EDS 


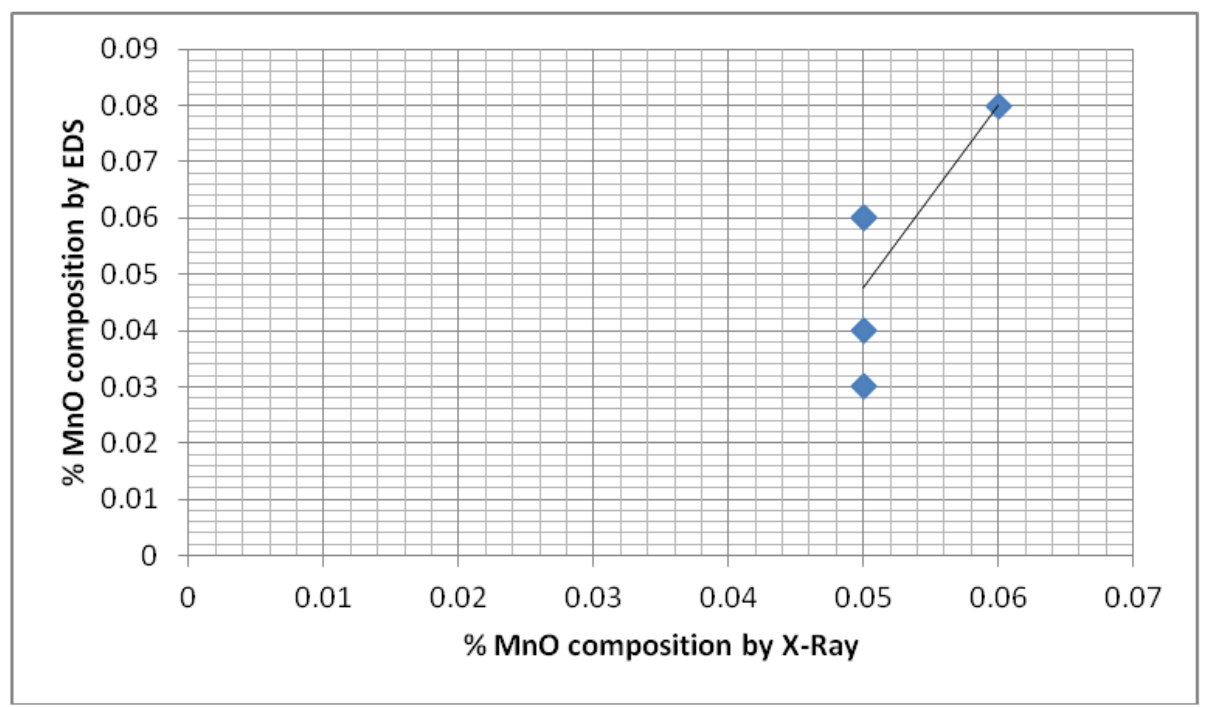

Figure 22. Plot of \% MnO composition by $\mathrm{X}$-ray against \% MnO composition determined by SEM-EDS

Table 3. Representation of some trace elements compositions of granite S1A-S5A sample

\begin{tabular}{|l|l|l|l|l|l|}
\hline Sample No. & 01A & 02A & 03A & 04A & 05A \\
\hline $\begin{array}{c}\text { Trace } \\
\text { Element }\end{array}$ & $\begin{array}{l}\text { Composition } \\
(\mathrm{ppm})\end{array}$ & $\begin{array}{l}\text { Composition } \\
(\mathrm{ppm})\end{array}$ & $\begin{array}{l}\text { Composition } \\
(\mathrm{ppm})\end{array}$ & $\begin{array}{l}\text { Composition } \\
(\mathrm{ppm})\end{array}$ & $\begin{array}{l}\text { Composition } \\
(\mathrm{ppm})\end{array}$ \\
\hline $\mathrm{Ba}$ & 800 & 805 & 850 & 750 & 807 \\
\hline $\mathrm{Cr}$ & 4.07 & 4.2 & 4.5 & 6.0 & 6.8 \\
\hline $\mathrm{Cu}$ & 34 & 30 & 37 & 41 & 27 \\
\hline $\mathrm{Ni}$ & 24 & 15 & 7 & 15 & 9 \\
\hline $\mathrm{Rb}$ & 92.5 & 93.50 & 87.5 & 95.4 & 110 \\
\hline $\mathrm{Sr}$ & 280 & 224 & 247 & 289 & 257 \\
\hline $\mathrm{Pb}$ & 32 & 14 & 37 & 25 & 19 \\
\hline $\mathrm{Nb}$ & 4.5 & 8.4 & 9.5 & 9.8 & 4.7 \\
\hline $\mathrm{Zr}$ & 32.6 & 111.4 & 80.6 & 98.0 & 60.8 \\
\hline $\mathrm{Zn}$ & 35 & 36 & 37 & 41 & 40.2 \\
\hline $\mathrm{Sn}$ & 0.75 & 0.70 & 0.75 & 0.72 & 0.77 \\
\hline
\end{tabular}

The total content of $\mathrm{Ba}, \mathrm{Cr}, \mathrm{Cu}, \mathrm{Ni}, \mathrm{Rb}, \mathrm{Sr}, \mathrm{Pb}, \mathrm{Nb}, \mathrm{Zr}, \mathrm{Zn}$, and Sn have been determined (Pawloski and Calif 1986,Xie et.al 2018 and Regelink 2014) and recorded in table 3. The heavy metals content in the rocks are consistently lower . Heavy metals have low mobility in relation to $\mathrm{Ca}^{++}$and $\mathrm{Mg}^{++}$and high persistent in the environment. $\mathrm{Ba}$ is associated with $\mathrm{K}$ because of similar in ionic ratio. Low content of heavy metals in rocks are consistent with very low metal content of the granitic parent material. The use of SEM -EDS is important to confirm the presence of elemental composition of the minerals. . Among the trace elements the precession and therefore accuracy of $\mathrm{Ni}, \mathrm{Cr}$, and $\mathrm{Ba}$ is significantly less than for $\mathrm{Rb}, \mathrm{Sr}, \mathrm{Zr}, \mathrm{Nb}, \mathrm{Cu}$ and $\mathrm{Zn}, \mathrm{Ba}$. $\mathrm{Ni}, \mathrm{Cr}$, and $\mathrm{Ba}$ are regarded as only semiquantative below $30 \mathrm{ppm}$ level, $\mathrm{Pb}, \mathrm{Sr}, \mathrm{Zr}$, have satisfactory precesion and accuracy down 1 to $3 \mathrm{ppm}$. Figure 23 to 29 shows the plot of trace element with $\mathrm{SiO} 2$ and $\mathrm{A} 12 \mathrm{O} 3$ compositon. Figure 23 shows that $\mathrm{Pb}$ concentration is increasing with $\mathrm{SiO} 2$ concentartion. On the other hand all other element shows almost constant composition with respect $\mathrm{SiO} 2$ and $\mathrm{Al} 2 \mathrm{O} 3$ composition. Figure 27,28 and 29 shows the variation $\mathrm{Ba}, \mathrm{Pb}$ and $\mathrm{Zr}$ with $\mathrm{Al} 2 \mathrm{O} 3$ which shows uniform distribution of these metal in all the five samples. 


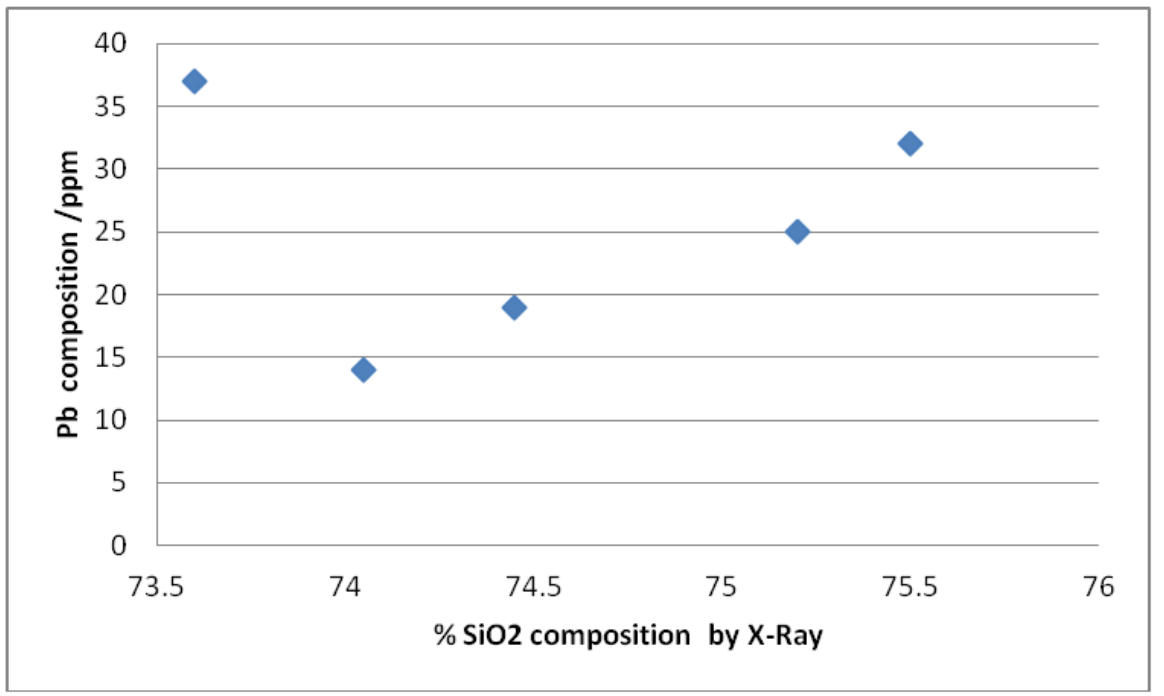

Figure 23. Plot of $\% \mathrm{Si}_{2} \mathrm{O}_{3}$ composition by $\mathrm{X}$-ray against $\mathrm{Pb} / \mathrm{ppm}$

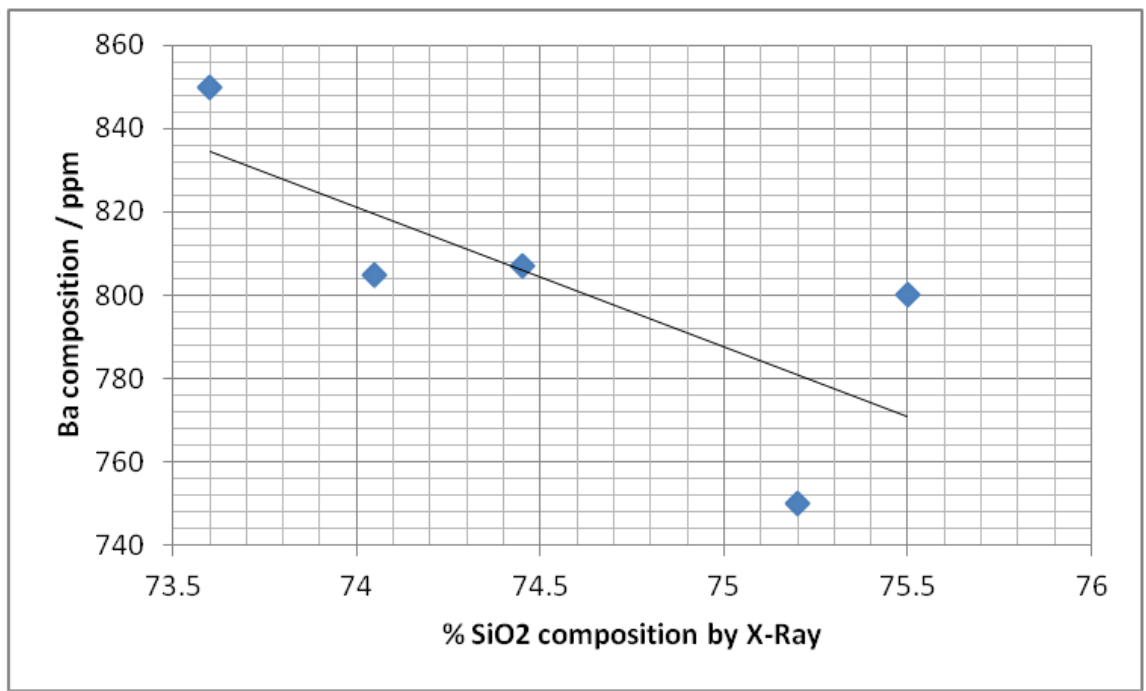

Figure 24. Plot of $\% \mathrm{Si}_{2} \mathrm{O}_{3}$ composition by $\mathrm{X}$-ray against $\mathrm{Ba} / \mathrm{ppm}$

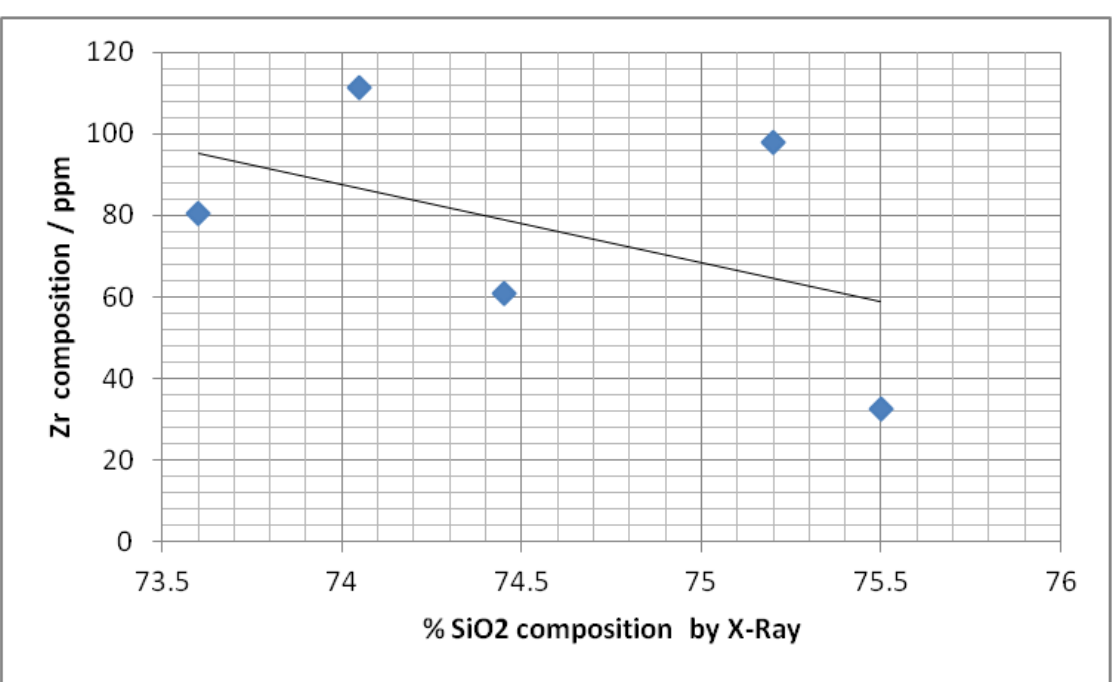

Figure 25. Plot of $\% \mathrm{Si}_{2} \mathrm{O}_{3}$ composition by X-ray against $\mathrm{Zr} / \mathrm{ppm}$ 


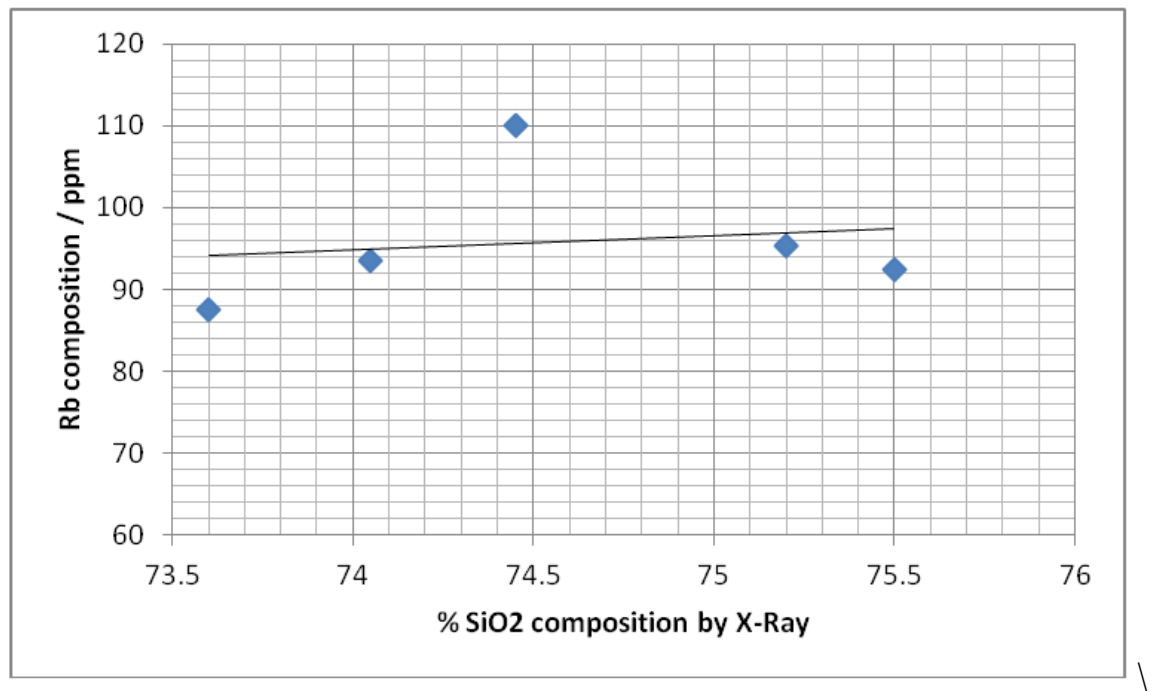

Figure 26. Plot of $\% \mathrm{Si}_{2} \mathrm{O}_{3}$ composition by X-ray against $\mathrm{Rb} / \mathrm{ppm}$

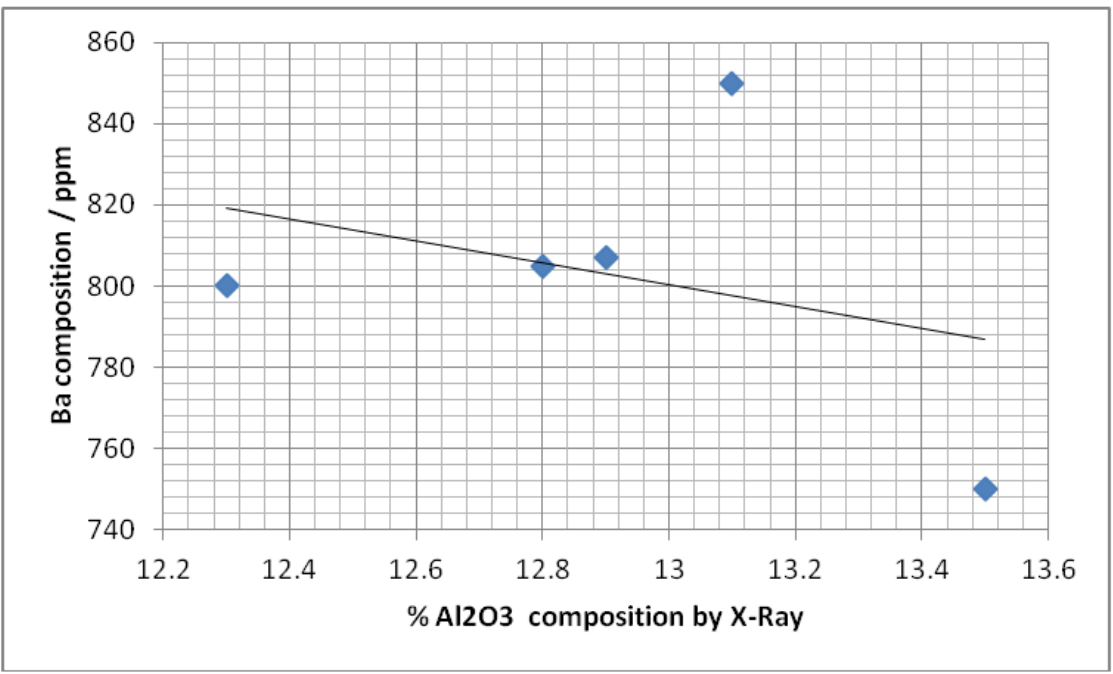

Figure 27. Plot of $\% \mathrm{Al}_{2} \mathrm{O}_{3}$ composition by $\mathrm{X}$-ray against $\mathrm{Ba} / \mathrm{ppm}$

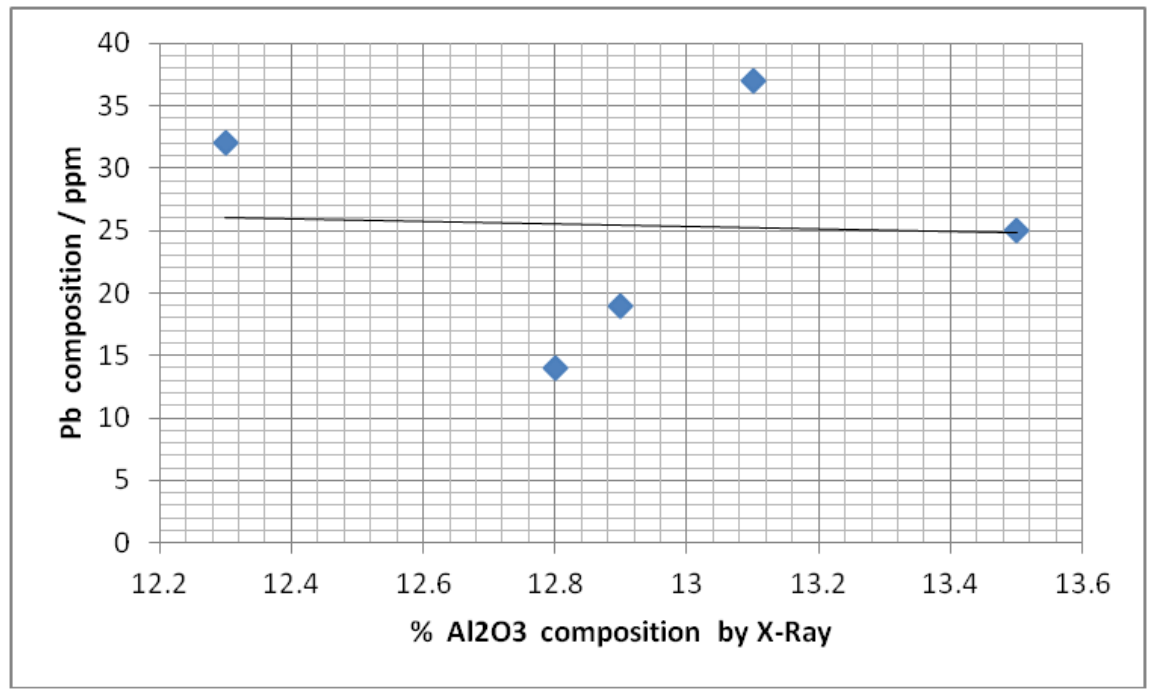

Figure 28. Plot of $\% \mathrm{Al}_{2} \mathrm{O}_{3}$ composition by $\mathrm{X}$-ray against $\mathrm{Pb} / \mathrm{ppm}$ 


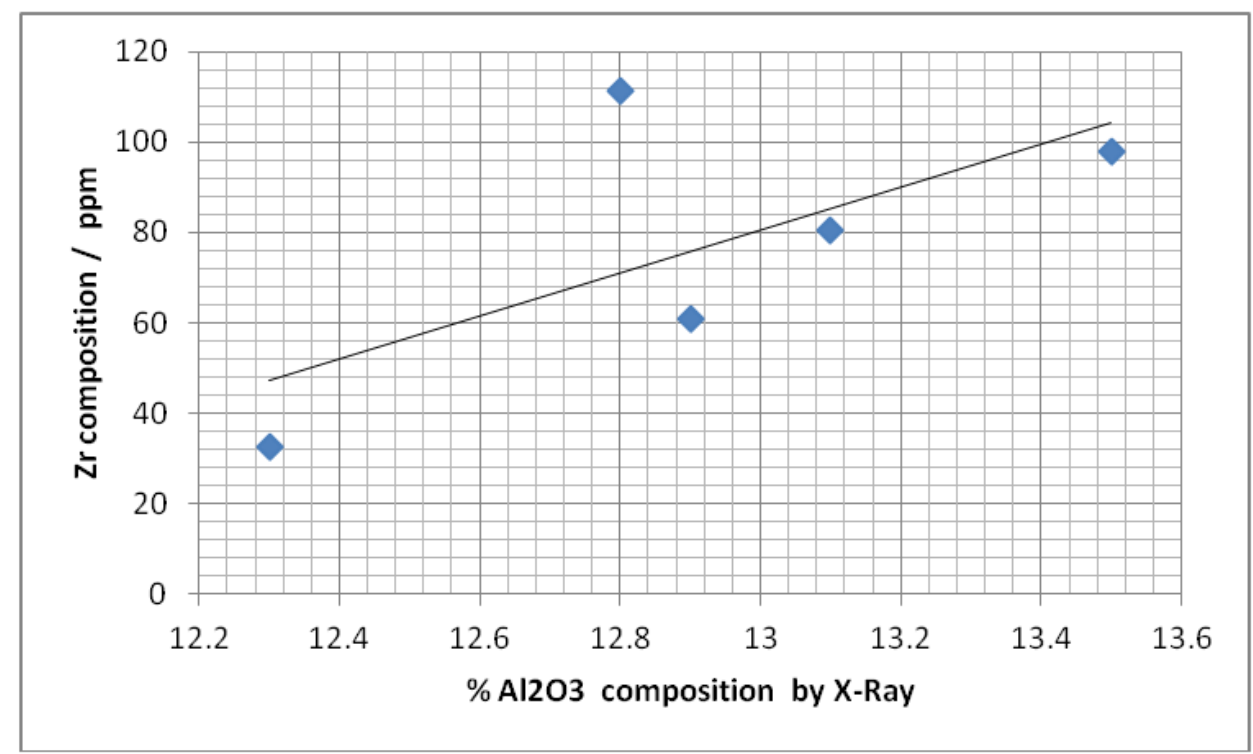

Figure 29. Plot of $\% \mathrm{Al}_{2} \mathrm{O}_{3}$ composition by X-ray against $\mathrm{Zr} / \mathrm{ppm}$

Figure 30 and 31 shows that plot of constituent oxides against \% oxides determined by XRD and and figure 31 determined by SEM-EDS shows are very close to standard mean value composition of Jharkhand granite.

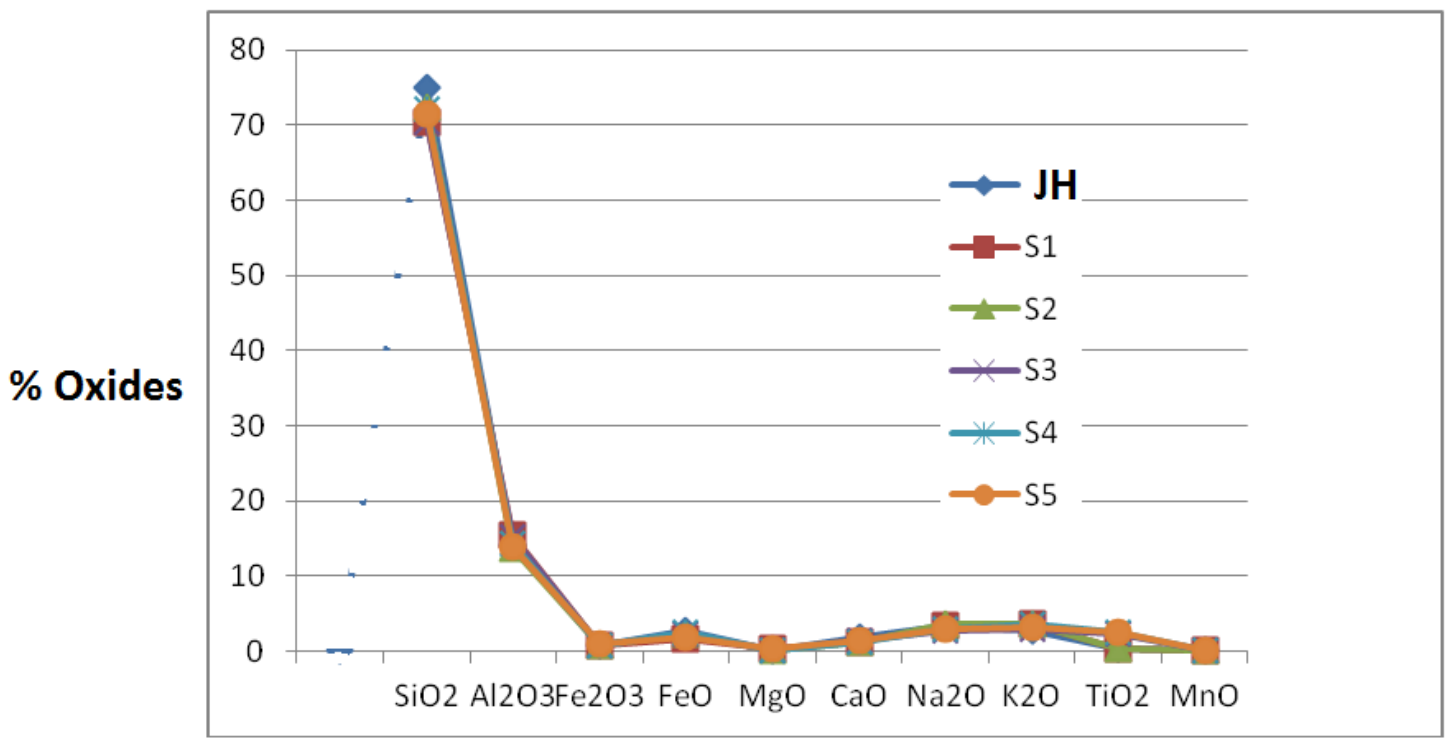

\section{Constituent Oxides}

Figure 30. Plot of chemical composition of constituent oxides with \% oxides of granite sample determined by X-Ray sepctrophotmeter

JH-Jharkhand average composition of granite

S1A-Sample composition Granite of S1A

S2A-Sample composition Granite of S2A

S3A-Sample composition Granite of S3A

S4A-Sample composition Granite of S4A

S5A-Sample composition Granite of S5A 


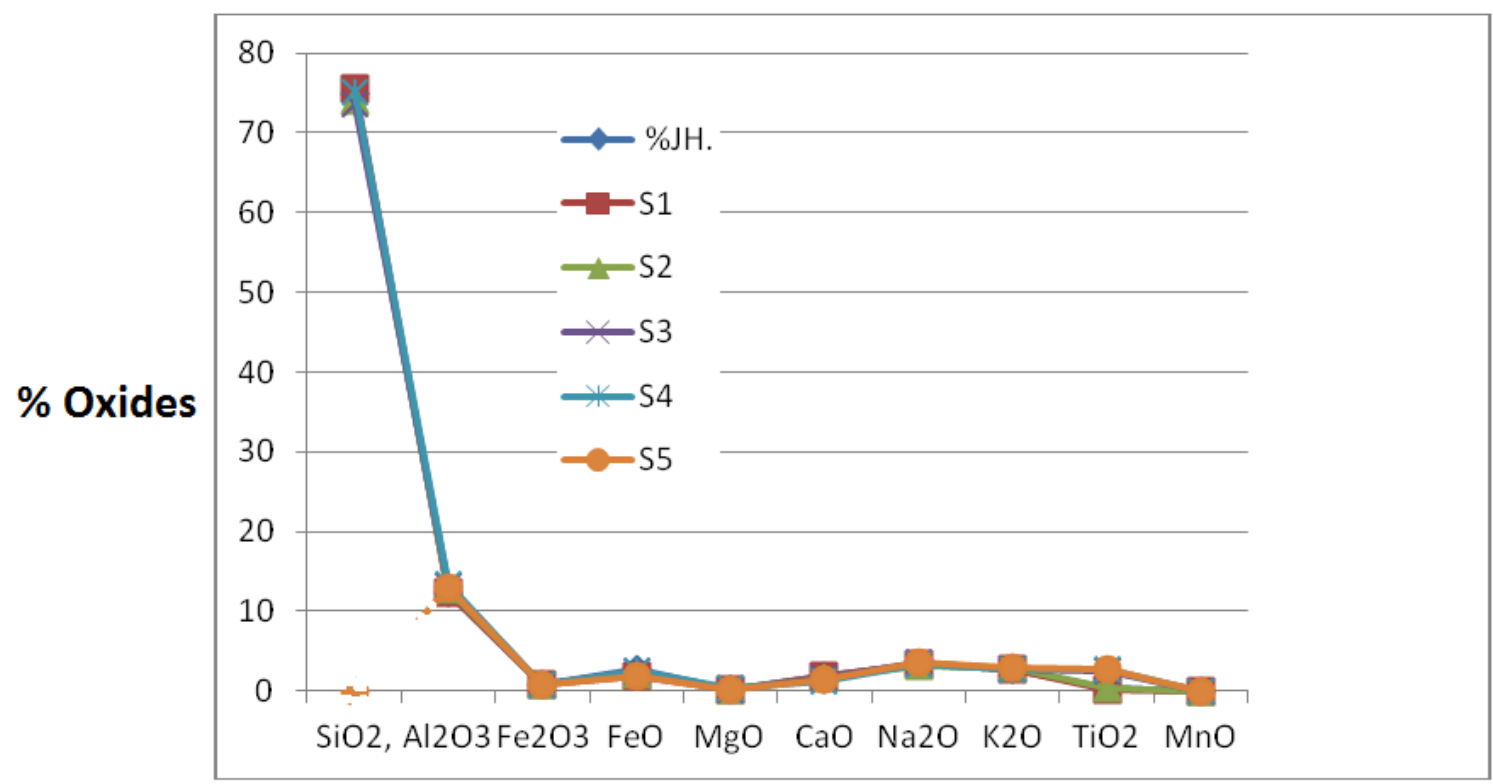

\section{Constituent Oxides}

Figure 31. Plot of chemical composition of constituent oxides with \% oxides of granite sample determined by SEM-EDS

JH-Jharkhand average composition of granite

S1A-Sample composition Granite of S1A

S2A-Sample composition Granite of S2A

S3A-Sample composition Granite of S3A

S4A-Sample composition Granite of S4A

S5A-Sample composition Granite of S5A

\section{Results and Discussion}

Five rocks samples S1A-S5A were subjected for XRD and SEM-EDS analysis. The XRD spectrum are shown in figure 1-5 and data are recorded in table 1. The SEM micro- photographs are shown in figure 6-10, EDS spectra are shown in figure 11-16 and data are tabulated in table 2. It is clear that the photograph that bright portion is composed by quartz. It is clear from the table 1 and 2 that rock are composed of mainly 10 minerals out of which silica have the highest composition $70-75 \%$ followed by alumina $12-14 \%$. The plot of X-Ray composition against SEM-EDS composition for various minerals shows that these two technique have good agreement within the experimental limits. The variation of heavy metals with respect to silica composition are shown in figure $23-26$ shows that variation of heavy metals are almost uniform in the granite matrix. Figure 26-28 shows the variation of heavy metals with respect to $\mathrm{Al}_{2} \mathrm{O}_{3}$ composition which is also uniform. The trace metals data obtained by X-Ray are recorded in table 3. Figure 30-31 shows that XRD and SEM-EDS plots are in good agreement. On the basis of XRD and SEM-EDS data, rock was classified as Peraluminius rock.

Major element data of five samples are shown in table $1 \& 2$ indicate that the granite gneiss are high in silica (70-75\%) and alumina $12-14 \%$ content, $\mathrm{Na}_{2} \mathrm{O}(3-4 \%)$ and $\mathrm{K}_{2} \mathrm{O}(2-3 \%)$. The rocks are characterized by total iron content as $\mathrm{Fe}_{2} \mathrm{O}_{3}$ from 0 to $1 \%, \mathrm{CaO}(0-2 \%)$. A typical plot of granite percentage against constituents of oxide with average composition of graniteis shown in figure 30-31. The trace elements were also analysed by X-ray technique and shown in table 3 . Granite rocks analysed have been classified as S-type granitoids and have relation with collisional orogenies and have tin, tunguston and silver deposite as valuable minerals. Petrography(Ridley 2012) deals with the identification of minerals, textures and microstructures of the different lithological units of the area figure 6-10. As the major part of the area is covered by quartz and muscovite. The rock is essentially composed of $\mathrm{SiO}_{2}, \mathrm{Al}_{2} \mathrm{O}_{3}, \mathrm{FeO}$ and $\mathrm{K}_{2} \mathrm{O}$. $\mathrm{SiO}_{2}$ constitutes $70-75 \%$ of the rock by weight. Alumina constitutes $13-16 \%$ of the total weight of the rock. Perthitic intergrowth are common and inclusions of $\mathrm{FeO}, \mathrm{CaO}$ are observed in microcline, $\mathrm{K}_{2} \mathrm{O}$ constitutes 2-4 \% of the rock. The grains show preferred orientation. Titanite, associated with $\mathrm{K}_{2} \mathrm{O}$ and $\mathrm{Fe}_{2} \mathrm{O}_{3}$ is common. Zircon grains are rounded to sub-rounded. 
On the basis of geochemical compositions and petrographic characteristics five samples of granites were collected. Major and trace element data for all granites are listed in table 3. Granite is a medium-to coarse-grained igneous rock with essential quartz and muscovite. Granites (Cross 1903 \& Maitre 2002) can be subdivided on the basis of their chemistry into peralkaline, metaluminous, and peraluminous on the basis of the ratio $\mathrm{Al}_{2} \mathrm{O}_{3} /\left(\mathrm{Na}_{2} \mathrm{O}+\mathrm{K}_{2} \mathrm{O}+\mathrm{CaO}\right)$. The related terminology is:

(i) peraluminous: $\mathrm{Al}_{2} \mathrm{O}_{3}>\left(\mathrm{Na}_{2} \mathrm{O}+\mathrm{K}_{2} \mathrm{O}+\mathrm{CaO}\right)$ or $\mathrm{Al}_{2} \mathrm{O}_{3} /\left(\mathrm{Na}_{2} \mathrm{O}+\mathrm{K}_{2} \mathrm{O}+\mathrm{CaO}\right)>1.1$; Rock will probably have muscovite and may have garnet; will be corundum-normative.

(ii) metaluminous: $\mathrm{Al}_{2} \mathrm{O}_{3}<\left(\mathrm{Na}_{2} \mathrm{O}+\mathrm{K}_{2} \mathrm{O}+\mathrm{CaO}\right)$ but $\mathrm{Al}_{2} \mathrm{O}_{3}>\left(\mathrm{Na}_{2} \mathrm{O}+\mathrm{K}_{2} \mathrm{O}\right)$ or $\mathrm{Al}_{2} \mathrm{O}_{3} /\left(\mathrm{Na}_{2} \mathrm{O}+\mathrm{K}_{2} \mathrm{O}+\mathrm{CaO}\right)>1.0$; rock may have hornblende

(iii) sub aluminous: $\mathrm{Al}_{2} \mathrm{O}_{3}<\left(\mathrm{Na}_{2} \mathrm{O}+\mathrm{K}_{2} \mathrm{O}+\mathrm{CaO}\right)$ but $\mathrm{Al}_{2} \mathrm{O}_{3}=\left(\mathrm{Na}_{2} \mathrm{O}+\mathrm{K}_{2} \mathrm{O}\right)$; $\mathrm{Al}_{2} \mathrm{O}_{3} /\left(\mathrm{Na}_{2} \mathrm{O}+\mathrm{K}_{2} \mathrm{O}+\mathrm{CaO}\right)<1.0$; rock will probably have hornblende.

(iv) peralkaline: $\mathrm{Al}_{2} \mathrm{O}_{3}<\left(\mathrm{Na}_{2} \mathrm{O}+\mathrm{K}_{2} \mathrm{O}\right)$ or $\mathrm{Al}_{2} \mathrm{O}_{3} /\left(\mathrm{Na}_{2} \mathrm{O}+\mathrm{K}_{2} \mathrm{O}+\mathrm{CaO}\right)<<1.0$; rock will Peraluminous rock probably have lot of $\mathrm{K}$-feldspar. It is clear from the table 1 and table 2 that $\mathrm{Al}_{2} \mathrm{O}_{3} /\left(\mathrm{Na}_{2} \mathrm{O}+\mathrm{K}_{2} \mathrm{O}+\mathrm{CaO}\right)=1.77$ This indicate rocks is Peraluminious and will have muscovite and may have garnet and corundum.

Peraluminous rocks (Willner 1990) are igneous rocks that have a molar proportion of aluminium oxide greater than that of sodium oxide, potassium oxide and calcium oxide combined as compared with peralkaline, metaluminous, and subaluminous. Peraluminous minerals include biotite, muscovite, cordierite, andalusite and garnet. Peraluminous rocks are igneous rocks that have a molecular proportion of aluminium oxide higher than the combination of sodium oxide, potassium oxide and calcium oxide (Blatt 1995). This contrasts with peralkaline in which the alkalis are higher, metaluminous where aluminium oxide concentration is lower than the combination, but above the alkalis, and subaluminous in which aluminia concentration is lower than the combination.

Peraluminous corresponds to the aluminum saturation index values greater than 1 (Ludington 2008) Peralumneous magmas can form S-type granitoids and have been linked to collisional orogenies and to the formation of tin, tungsten and silver deposits. (Mlynarczyk 2005). The mineral chemical formula have been calculated by CQMA method (Ligarski 2017, Klika 2016) and summarized in table 4.

Table 4. The crystallochemical formulas of Granite Minerals

\begin{tabular}{|c|c|c|}
\hline $\begin{array}{l}\text { Sl.N } \\
\text { o }\end{array}$ & Mineral names & Chemical Formula \\
\hline 1. & Quartz & $\mathrm{SiO}_{2}$ \\
\hline 2. & Muscovite & $\left(\mathrm{KF}_{2}\right)\left(\mathrm{Al}_{2} \mathrm{O}_{3}\right)_{3}\left(\mathrm{SiO}_{2}\right)_{6}$ \\
\hline 3. & Chlorite & $(\mathrm{Fe}, \mathrm{Mg}, \mathrm{Al})_{6}(\mathrm{Si}, \mathrm{Al})_{4} \mathrm{O}_{10}(\mathrm{OH})_{8}$ \\
\hline 4. & Albite & ${\mathrm{NaAlSi} 3 \mathrm{O}_{8}}$ \\
\hline 5. & Kaolinite & $\mathrm{Al}_{2} \mathrm{O}_{3}\left(\mathrm{SiO}_{2}\right)_{2}\left(\mathrm{H}_{2} \mathrm{O}\right)_{2}$ \\
\hline 6. & Pyrite & $\mathrm{FeS}$ \\
\hline 7. & K-fieldpar & $\mathrm{KAlSi}_{3} \mathrm{O}_{8}-\mathrm{NaAlSi}_{3} \mathrm{O}_{8}-\mathrm{CaAl}_{2} \mathrm{~S}_{2} \mathrm{O}_{8}$ \\
\hline 8. & Biotite & $\mathrm{K}\left(\mathrm{Mg}, \mathrm{Fe}^{++}\right)_{3}\left[\mathrm{AlSi}_{3} \mathrm{O}_{10}(\mathrm{HF})_{2}\right.$ \\
\hline 9. & Amphibole & $\mathrm{SiO}_{4}$ \\
\hline 10. & Illite & $\begin{array}{l}\left(\mathrm{KH}_{3} \mathrm{O}(\mathrm{Al}, \mathrm{Mg}, \mathrm{Fe})_{2}(\mathrm{SiAl})_{4} \mathrm{O}_{10}\left[(\mathrm{OH})_{2}(\mathrm{H}\right.\right. \\
\left.\left.{ }_{2} \mathrm{O}\right)\right]\end{array}$ \\
\hline 11. & Calcite & $\mathrm{CaCO}_{3}$ \\
\hline 12. & Plagioclase & $(\mathrm{Na}, \mathrm{Ca})(\mathrm{Si}, \mathrm{Al})_{4} \mathrm{O}_{8}$ \\
\hline 13. & Apatite & {$\left[\mathrm{Ca}_{5}\left(\mathrm{PO}_{4}\right)_{3}(\mathrm{OH}, \mathrm{F}, \mathrm{Cl}]\right.$} \\
\hline
\end{tabular}




\section{Conclusion}

Deoghar Jharkhand granite were analysed by two different X-ray and SEM-EDS technique. Remarkable good agreement were found between XRD quantitative analysis and SEM -EDS analysis. Mineral composition of samples investigated by XRD analysis reveal that rocks, granite silica SiO2 (70-75\%), Al2O3 (12-14 \%) as shown in table 1 and SEM -EDS analysis shown in table 2. It is confirmed that $\mathrm{Si}$ is highest composition followed By alumina in the granite rock sample S1A-S5A. Further, rocks have been classified as peraluminus which can form S-type granitoids. The rocks also contain valuable minerals in trace amount in ppm range. The composition of silica and Alumina have been plotted for $\mathrm{Na} 2 \mathrm{O}, \mathrm{K} 2 \mathrm{O}$, $\mathrm{FeO}, \mathrm{TiO} 2$ and $\mathrm{MnO}$ determined by two different technique have good agreement, and close to standard mean value of Jharkhand. Further silica and alumina dependence on trace element shows that $\mathrm{Pb}$ is increasing with silica on other hand other element shows the constant composition with silica and alumina..

\section{References}

Blatt, H., \& Robert, J. T. (1995). Petrology. (2nd ed.). Freeman.

Behzad, H., Nasser, A., \& Jafar, S. (2016). Mineralogy and Geochemistry of the Upper. Paleocene Shales from Goouydaraq-Goouradaraq, East Azarbaijan, NW Iran. Open Journal of Geology, 6, 1096-1117. Retrieved from http://www.scirp.org/journal/ojg

Carlton, R. A., Lyman, C. E., \& Roberts, J. E. (2004). Accuracy and precision of quantitative energy-dispersive x-ray spectrometry in the environmental scanning electron microscope. Scanning: The Journal of Scanning Microscopies, 26(4), 167-174.

Christy, A. G., Mills, S. J., Kampf, A. R., Housley, R. M., Thorne, B., \& Marty, J. (2016). The relationship between mineral composition, crystal structure and paragenetic sequence: the case of secondary Te mineralization at the Bird Nest drift, Otto Mountain, California, USA. Mineralogical Magazine, 80(2), 291-310. https://doi.org/10.1180/minmag.2016.080.001

Clarke, D. B., \& Upton, B. G. J. (1971). Tertiary basalts of Baffin Island: field relations and tectonic setting. Canadian Journal of Earth Sciences, 8(2), 248-258. https://doi.org/10.1139/e71-025

Cross, C. W., Iddings, J. P., Pirsson, L. V., \& Washington, H. S. (1903). Quantitative classification of igneous rocks.

Dutch, S. (2009). Classification of Igneous Rocks. Archived from the original on 2010-06-03. Retrieved 15 September 2009.

Faryad, S. W. (1995). Petrology and phase relations of low-grade high-pressure metasediments from the Meliata Unit (West Carpathians, Slovakia). European Journal of Mineralogy, 71-88. https://doi.org/10.1127/ejm/7/1/0071

Faryad, S. W., \& Cuthbert, S. J. (2020). High-temperature overprint in (U) HPM rocks exhumed from subduction zones; A product of isothermal decompression or a consequence of slab break-off (slab rollback)?. Earth-Science Reviews, 103-108. https://doi.org/10.1016/j.earscirev.2020.103108

Faryad, S. W., \& Fišera, M. (2015). Olivine-bearing symplectites in fractured garnet from eclogite, Moldanubian Zone (Bohemian Massif)-a short-lived, granulite facies event. Journal of Metamorphic Geology, 33(6), 597-612. https://doi.org/10.1111/jmg.12135

Fisher, R. V., \& Schmincke, H. U. (1984). Pyroclastic Rocks. Berlin, Springer-Verlag. https://doi.org/10.1007/978-3-642-74864-6

Granite in India. (1990). Training, Mining Research and Publication Division, Bulletin No. 21, Indian Bureau of Mines Nagpur, 3.

Hubbard, C. R., \& Snyder, R. L. (1988). RIR-measurement and use in quantitative XRD. Powder Diffraction, 3(2), 74-77. https://doi.org/10.1017/S0885715600013257

Indian Mineral Year Book (2013). Part III Mineral Review, 52 edition Grnite Advance Relese. Indian Bureau of Mines Nagpur January 2015.

Klika, Z., Kolomazník, I., Matýsek, D., \& Kliková, C. (2016). Critical evaluation of a new method for quantitative determination of minerals in solid samples. Crystal Research and Technology, 51(4), 249-264. https://doi.org/10.1002/crat.201500214

Le Maitre, R. W., Streckeisen, A., Zanettin, B., Le Bas, M. J., Bonin, B., \& Bateman, P. (Eds.). (2005). Igneous rocks: a classification and glossary of terms: recommendations of the International Union of Geological Sciences Subcommission on the Systematics of Igneous Rocks. Cambridge University Press.

Ludington, S., Victor, G., \& Mossotti. (2008). Aluminum saturation, alkalinity, and magma series. 33rd International 
Geologic Congress. Retrieved 22 September 2013.

Middlemost, E. A. (1986). Magmas and magmatic rocks: an introduction to igneous petrology.

Mlynarczyk, M. S., \& Williams-Jones, A. E. (2005). The role of collisional tectonics in the metallogeny of the Central Andean tin belt. Earth and Planetary Science Letters, 240(3-4), 656-667. https://doi.org/10.1016/j.eps1.2005.09.047

Omotoso, O., McCarty, D. K., Hillier, S., \& Kleeberg, R. (2006). Some successful approaches to quantitative mineral analysis as revealed by the 3rd Reynolds Cup contest. Clays and Clay Minerals, 54(6), 748-760. https://doi.org/10.1346/CCMN.2006.0540609

Pawloski, G. A. (1986). U.S. Patent No. 4,592,082. Washington, DC: U.S. Patent and Trademark Office.

Regelink, J. A. (2014). Mincomp-a program to calculate a likely mineralogical bulk composition from XRD and XRF results. Research Minor TA-MI-077.

Ridley, W. I. (2010). 15. Petrology of Associated Igneous Rocks.

Shao, J. Q., \& Yang, S. Y. (2012). Does chemical index of alteration (CIA) reflect silicate weathering and monsoonal climate in the Changjiang River basin? Chin Sci Bull, 57, 1178-1187. https://doi.org/10.1007/s11434-011-4954-5

Willner, A., Schreyer, W., \& Moore, J. M. (1990). Peraluminous metamorphic rocks from the Namaqualand Metamorphic Complex (South Africa): Geochemical evidence for an exhalation-related, sedimentary origin in a Mid-Proterozoic rift system. Chemical Geology, 81(3), 221-240. https://doi.org/10.1016/0009-2541(90)90117-P

Xie, Y., Lu, G., Yang, C., Qu, L., Chen, M., Guo, C., \& Dang, Z. (2018). Mineralogical characteristics of sediments and heavy metal mobilization along a river watershed affected by acid mine drainage. PloS one, 13(1). https://doi.org/10.1371/journal.pone.0190010

Zhou, X., Liu, D., Bu, H., Deng, L., Liu, H., Yuan, P., ... \& Song, H. (2018). XRD-based quantitative analysis of clay minerals using reference intensity ratios, mineral intensity factors, Rietveld, and full pattern summation methods: A critical review. Solid Earth Sciences, 3(1), 16-29. https://doi.org/10.1016/j.sesci.2017.12.002

\section{Copyrights}

Copyright for this article is retained by the author(s), with first publication rights granted to the journal.

This is an open-access article distributed under the terms and conditions of the Creative Commons Attribution license (http://creativecommons.org/licenses/by/4.0/). 